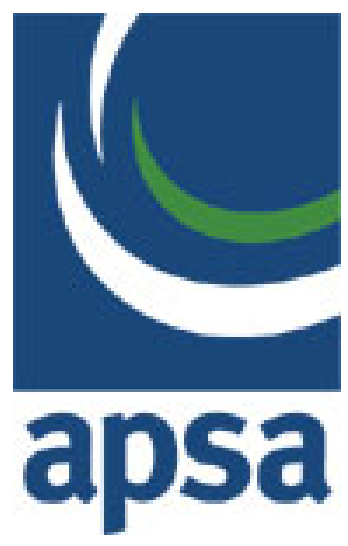

The Structure of Class Conflict in Democratic Capitalist Societies

Author(s): Adam Przeworski and Michael Wallerstein

Source: The American Political Science Review, Vol. 76, No. 2 (Jun., 1982), pp. 215-238

Published by: American Political Science Association

Stable URL: http://www.jstor.org/stable/1961105

Accessed: 13/06/2011 13:09

Your use of the JSTOR archive indicates your acceptance of JSTOR's Terms and Conditions of Use, available at http://www.jstor.org/page/info/about/policies/terms.jsp. JSTOR's Terms and Conditions of Use provides, in part, that unless you have obtained prior permission, you may not download an entire issue of a journal or multiple copies of articles, and you may use content in the JSTOR archive only for your personal, non-commercial use.

Please contact the publisher regarding any further use of this work. Publisher contact information may be obtained at http://www.jstor.org/action/showPublisher?publisherCode=apsa.

Each copy of any part of a JSTOR transmission must contain the same copyright notice that appears on the screen or printed page of such transmission.

JSTOR is a not-for-profit service that helps scholars, researchers, and students discover, use, and build upon a wide range of content in a trusted digital archive. We use information technology and tools to increase productivity and facilitate new forms of scholarship. For more information about JSTOR, please contact support@jstor.org. 


\title{
The Structure of Class Conflict in Democratic Capitalist Societies
}

\author{
ADAM PRZEWORSKI \\ Michael WALLERSTEIN \\ University of Chicago
}

\begin{abstract}
The article presents a theory of class conflict between workers and capitalists who pursue their material interests under a form of societal organization that combines private ownership of instruments of production with representative political institutions. There exist economic and political conditions under which both classes would simultaneously choose courses of action that constitute a class compromise: workers consent to the institution of profit and capitalists to democratic institutions through which workers can effectively press claims for material gains. When these conditions hold and a compromise is in force, the role of the state consists in institutionalizing, coordinating, and enforcing the terms of a compromise that represents the preferences of workers as well as capitalists.
\end{abstract}

The combination of private ownership of the instruments of production with representative political institutions based on widespread suffrage constitutes a compromise between workers, who consent to the private appropriation of profit by owners of capital, and capitalists, who accept the democratic institutions through which workers can make effective claims for an improvement of their material conditions.

This form of societal organization was considered to be inherently unstable by Marx, who believed that capitalist democracy is "only the political form of revolution of bourgeois society and not its conservative form of life," (1934, p. 18) "only a spasmodic, exceptional state of things . . impossible as the normal form of society." (1972, p. 198) ${ }^{1}$ Once introduced, Marx thought, political democracy would either be extended to the "social realm" by workers nationalizing the means of production or subverted by capitalists using the ownership of capital to restore their political power. Yet in many countries, capitalist democracy has persisted over long periods of time.

Marx's predictions may have been false for at least two distinct reasons. His followers have tended to accept a model of conflict in which interests of classes are irreconcilably opposed to each other, a model that implies that workers should always be hostile to capitalism and capitalists. If this model is correct and if capitalism nevertheless survives in its democratic form, it

This work has been supported by a grant from the National Science Foundation, No. SOC 78-04595.

${ }^{1}$ See Przeworski (1980). must be the result of the activities of some institutions, typically thought to be the state, which provide physical repression, ideological domination, cooptation of workers' leaders, or whatever else is necessary to perpetuate capitalism in the face of the permanent threat posed by workers.

But Marx may have erred in analyzing the nature of this conflict. Interests of workers and capitalists may not be irreconcilable under all circumstances, and workers may see the choice between capitalism and socialism differently depending upon the specific political and economic conditions under which they live. Their option may be the one defined by John Mitchell, President of the United Mine Workers, at the turn of the century: "Trade unionism is not irrevocably committed to the maintenance of the wage system, nor is it irrevocably committed to its abolition. It demands the constant improvement of the condition of the workingmen, if possible, by the maintenance of the present wage system, if not possible, by its ultimate abolition." (Quoted by Sombart 1976, p. 19.) And if workers opt for capitalism under some conditions, then the activities of the state acquire a different significance: the state institutionalizes, coordinates, and enforces compromises reached by a class coalition that encompasses both workers and capitalists.

Our purpose is to examine the structure of class conflict over material interests between workers and capitalists in democratic capitalist societies and to analyze the consequences of this structure for the theory of the state. We assume throughout that both workers and capitalists would adopt those courses of action which are most likely to benefit them. Generically, four such outcomes are conceivable: (1) a democratic capitalist compromise, (2) capitalist democracy without a compro- 
mise (tug-of-war), (3) dictatorial capitalism, and (4) socialism. First we examine the outcomes of conflicts under capitalist democracy; that is, the choice between compromise and its absence when the means of production are privately owned and democratic political institutions are preserved. Then we compare the best outcome workers can obtain under capitalist democracy with their welfare associated with the strategy of transition to socialism. Finally, we comment on the implication of the compromise for the theory of the state.

\section{Capitalism and the Working Class}

In a capitalist society profit is a necessary condition of continued production, consumption, and employment. Although in any society some part of the product must be withheld from current consumption if production is to continue and consumption is to increase, the distinguishing characteristic of capitalism is that most investment occurs out of profits, that part of the product which is withheld from the immediate producers. It is upon profits that the renewal and enlargement of the capital stock depends. Hence, under capitalism private profit is a necessary condition for the improvement of the material conditions of any group in society. As Chancellor Schmidt put it, "The profits of enterprises today are the investments of tomorrow, and the investments of tomorrow are the employment of the day after" (Le Monde, July 16, 1976) and in place of employment he might as well have said production or consumption.

This dependence of accumulation upon profit can be formally described in a number of ways, among which we choose the simplest. We assume that net investment $\Delta K(t)$, where $K(t)$ is the capital stock, is equal to the rate of saving out of profits, $s$, multiplied by net profits, $P(t) .^{2}$

\footnotetext{
${ }^{2}$ We make, here, the strong assumption that the entire wage bill is consumed. It is not crucial to our argument, however. If we acknowledge that workers do save and, following Pasinetti (1962), rewrite equation (1) in the test as $\left.\Delta K(t)=s_{p} P(t)+s_{p} P(t)+Q(t)\right]$, where $s_{p}$ is the rate of saving out of profits, $P(t)$, and $s_{w}$ is the rate of saving out of wages, $W(t)$, and workers' interest income, $Q(t)$, we get a more complicated model with similar results. If workers receive the same rate of return as capitalists, the results are identical. If, however, capitalists gain a fee for investing workers' savings, the results concerning workers' strategic behavior remain the same while capitalists become somewhat more disposed to compromise.
}

That being said, the strong assumption that workers' net savings are negligible is not an unreasonable simplification for a society like the United States where gross

$$
\Delta K(t)=s P(t), s \leqslant 1
$$

In addition, we assume that the productivity of capital is constant and is measured by the output / capital ratio $1 / c .^{3}$

$$
1 / c=Y(t) / K(t)=\Delta Y(t) / \Delta K(t)
$$

Net output $Y(t)$ is divided into net profits, $P(t)$, and wages, $W(t){ }^{4}$

$$
Y(t)=P(t)+W(t)
$$

Solving the three equations yields the time path of output.

$$
Y(t+1)=(1+s / c) P(t)+W(t)
$$

Note that the quantity $s / c$ represents the increase of output per unit of profit when capitalists

personal saving minus investment in housing and minus investment by unincorporated business averaged 1.1 percent of disposable income between 1949 and 1970 (Wallerstein 1979). In contrast, the rate of corporate saving in the United States in roughly the same period was estimated to range from 40 to 60 percent of profits (Odling-Smee 1973).

${ }^{3}$ The capital-to-output ratio constitutes a cumulative effect of past decisions by capitalists and it changes rather slowly, although it may exhibit long-term trends (Helmstädter 1973). The values of this parameter are fairly well known (Helmstädter 1973; Clough 1968; Kuznets 1966; Maddison 1964). In our subsequent analysis we assume that $c=4$, as this value seems to be a reasonable estimate of the net incremental capital-tooutput ratio in the advanced capitalist economies.

${ }^{4}$ That part of the national income accruing to wage earners, which we have designated $W(t)$, is actually a composite of different types of income. To disaggregate somewhat, we could write: $W=w L+\bar{w}(N-L)$, or, alternatively, $\mathrm{W}=(\bar{w}-\bar{w}) L+w N$, where $N$ is the size of the adult population that does not own capital, $L$ is the number employed, $w$ is the average wage rate, and $W$ is the average transfer. Thus, $w$ is either the average transfer to the unemployed or a "reservation wage" (McDonald and Solow 1981), or a basic maintenance payment accruing to all $N$ independently of the employment status or a "citizen's wage" (Bowles and Gintis 1980) such as social security benefits, private pensions, and unemployment compensation. To proceed in this direction one must, first, modify our assumptions about production to include labor as a productive input; second, specify the preferences of workers over combinations of $w, \bar{w}$, and $L$, and third, stipulate who pays the citizen's wage. These modifications would be necessary to analyze class conflict over employment, rather than over investment and the distribution of income. This, however, is a project for the future. 
invest at the rate $s$ in an economy characterized by the capital/output ratio $c$ :

$$
s / c=\Delta Y(t) / P(t) .
$$

Since the rate of investment can be at most equal to one, the productivity of capital, $1 / c$, can be thought of as the upper bound on the increase of output due to each unit of profit.

Note finally that the rate of growth of such an economy depends upon the rate of profit and the rate of saving out of profit:

$$
\begin{aligned}
& \Delta Y(t) / Y(t)=s P(t) / c Y(t)=s P(t) / K(t)= \\
& s p(t),
\end{aligned}
$$

where $p(t)=P(t) / K(t)$ is the rate of profit. Hence the greater the rate of profit and the rate of investment out of profits, the greater the rate of growth. The rate of saving, $s$, characterizes the crucial aspect of the behavior of capitalists, since given the share of profit in the national income, their decisions to invest and thus to save determine the rate of growth of the economy.

Although profit is a necessary condition of economic growth, it is not a sufficient condition for the improvement of the material welfare of any particular group. First, capitalists may treat profits in ways that do not increase productivity: albeit under constraints, profits may be hoarded, consumed, exported, or just invested unproductively. Second, even if capitalists are frugal and efficient, no particular group can be in any way assured that it will be the beneficiary of the investment. Capitalists may themselves retain the entire additional output or they may share the gain exclusively with any of a number of potential political allies. Their market relation with workers ends as the cycle of production is completed and wages are paid, and there is nothing in the structure of the capitalist economic system that would guarantee that workers would benefit because a part of the product (the profit) is currently withheld from them.

Faced with this system, organized workers have the following options:

1. To claim the entire capital stock ("means of production") from capitalists and to reorganize the system of production so that the decision to withhold from current consumption would be made by all individuals qua citizens. The investment fund would be deducted directly from the gross product, profit having been abolished as a juridical and as an economic category. This strategy would constitute a step toward socialism.

2. To claim the entire product or even a part of the capital stock without reorganizing the process of withholding from current consumption. This is a militant economicist strategy.
3. To claim less than the entire product, thus leaving a part in the hands of capitalists as profit, in exchange for some assurance that future material conditions would improve as a consequence. This strategy opens room for a class compromise with capitalists.

\section{Class Compromise}

The structural conditions of the capitalist organization of production delimit the form of any possible class compromise. Since the appropriation of profit by capitalists is a necessary but not a sufficient condition for an improvement of the material welfare of workers under capitalism, a class compromise is possible only on the condition that workers are reasonably certain that future wages will increase as a consequence of current profits. Any compromise must have the following structure: workers consent to the perpetuation of profits as an institution in exchange for the prospect of improving their material welfare within some future period. In terms of such a compromise, capitalists retain the capacity to withhold a part of the product because the profit they appropriate is expected by workers to be saved, invested, and utilized to increase output, with part of the increase distributed as gains to workers.

This general logic need not be always stated explicitly as the form of a particular compromise between labor and capital. Indeed, during the early period of the development of the working-class movement this compromise was limited to the right of workers to associate, to bargain collectively, and to strike. Eventually formal corporatist arrangements and explicit norms appeared, pegging wage increases to exceed increases in the cost of living, or to equal the growth of productivity, or to depend upon competitiveness in the international system. The norm tying increases of wages to the growth of productivity became the foundation of the compromise established during the expansionist period between 1950 and 1970 . Nevertheless, whatever the explicit norm cementing a particular social compact, the underlying logic of compromise must relate future wages to current profits. The only conceivable reason for workers to consent voluntarily not to claim the capital stock is to treat current profits as a form of workers delegated investment. form

Hence, any class compromise must have the

$$
\Delta \hat{W}(t)=F(P(t-\mathrm{i})), \mathrm{i}=0,1, \ldots, \mathrm{k}, \ldots,
$$

where $\Delta \hat{W}(t)$ represents the increase of wages between any successive periods $t$ and $(t+1)$ associated with a particular compromise, $P(t-\mathrm{i})$ gives 
the history of profits, and $F$ is the rule that relates past profits to current wage increases. For the sake of simplicity, let this rule be

$$
\Delta \hat{W}(t)=r P(t), r>0 .
$$

A compromise is in force, therefore, when workers consent to any value of $r$ which constitutes less than a claim to the capital stock and capitalists consent to institutions that would make it reasonably certain that wages would increase as a function of profits according to some rule such as (8). Workers consent to a capitalist organization of production when they choose and follow in practice any strategies that make possible the perpetuation of capitalist relations. Capitalists in turn accept a compromise when they consent to institutions that would permit workers to process their claims with some success: basically unions, parties, and a relatively autonomous state. This class compromise is precisely that which Marx found to be unreasonable: workers stop short of seeking social emancipation, capitalists of attempting political restoration. Workers consent to capitalism; capitalists consent to democracy.

Since workers make their consent conditional upon obtaining wage increases equal to the proportion $r$ of current profits, this coefficient can be thought of as indicating the economic militancy of organized workers under particular historical conditions. A compromise is in force when workers are not so militant that their wage demands would make profits immediately negative, that is, when $r$ $<(1+s / c)$. This can be seen as follows: At any time $t$ capitalists appropriate the amount of profit equal to $P(t)$ and during the period $(t, t+1)$, they invest the fraction $s$ of $P(t)$ at a rate of return equal to $1 / c$. Therefore, at the time $(t+1)$, with regard to which workers make claims at $t$, capitalists will have the amount $(1+s / c) P(t)$. At time $(t+1)$ they pay wage increases equal to $r P(t)$. Hence, an $r=(1+s / c)$ is immediately confiscatory with regard to profits: it implies that workers appropriate the entire net product at $(t+1)$. Any $r$ larger than that means that workers claim capital stock.

Class compromise is expressed, therefore, in institutional arrangements that imply that some proportion $r$ of current profits is to be transformed into wage increases, where $r<(1+s / c)$. Class compromise is in force when workers and capitalists act in ways that presuppose the perpetuation of capitalist democracy as the form of organization of society.

\section{Workers' Strategy}

Organized workers would rationally opt for a compromise, consenting to profit as an institu- tion, if this compromise would be preferable both to the outcomes associated with greater economic militancy under capitalism and to the result they would expect to attain by adopting a strategy of transition to socialism. Eventually we will introduce some of the complications that arise when workers consider the socialist alternative, but at this moment we will be concerned only with comparisons of the welfare that workers can attain by choosing different degrees of economic militancy under capitalism.

At any time, let it be $T=0,1,2, \ldots$, workers decide how militant they should be economically, that is, what proportion of current profits they should immediately demand as wage increases. The effect of workers' decision made at time $t$ is irrevocable in the sense that the part of the product not transformed into wages is irretrievably forsaken by workers and appropriated by capitalists who alone decide whether or not to invest it.

Workers choose their strategy on the basis of their expectations about the future. They decide by comparing the alternative futures they expect to occur as the result of their current course of action. These expectations are shaped by workers' analysis of the reaction of capitalists to their own course of action and of workers' perception of their power to enforce a compromise if one were to be concluded. Hence these expectations are conditional: they are molded by the conditions that hold when a decision is to be made.

Workers opt for a compromise if they think it to be the best course of action at a particular time. Note that workers may not receive the returns they expected when the decision was made, but they base their decision on what they expect to happen; they have, after all, no other grounds on which to base it.

Workers base present decisions on their expectations for the future, but they do not commit themselves to choose the same course of action again under different conditions. Hence no compromise is made once and for all. Neither the workers' consent to capitalism nor the capitalists' consent to democracy constitutes consensus, some kind of prior and immutable agreement about societal organization that would hold regardless of whether or not the interests of each class are being realized within it. A compromise holds if and only if it is continually in the best interest of workers and capitalists and only if it is repeatedly remade. A compromise is not a commitment for some indefinite or even limited future; it is an outcome of strategies chosen today which today appear optimal. If the compromise is to last the day after, it must be made again the day after, and it will be made only if it constitutes the best solution 
the day after. ${ }^{5}$ Consent should not be seen as a state of mind or a prior commitment but as a characteristic of actions, of strategies, and of nothing beyond. Classes consent to a particular form of society when they choose strategies that entail the perpetuation of that form, because those strategies are in their best interests given the alternatives. Nothing else is involved.

How do workers decide upon their strategies? There are two considerations: the wages they expect in the future if the compromise holds and the risk that the compromise will not hold. Suppose first that actual wages follow the path stipulated by a compromise, that is, $W(t)=\hat{W}(t)$ for all $T$ $\leqslant t \leqslant T+h$, where $h$ is the horizon with which workers consider the future. If capitalists invest at the rate $s$ in the economy characterized by the productivity of capital $1 / c$, then the time path of compromise wages will depend upon the relation between $r$ and $s / c$. Recall that

$$
\begin{aligned}
\Delta Y(t)=\Delta P(t)+\Delta W(t)= & (s / c) P(t), \\
& (\text { from 3 and 5) }
\end{aligned}
$$

and

$$
\Delta W(t)=\Delta \hat{W}(t)=r P(t) .
$$

(from 8)

\footnotetext{
${ }^{5}$ Hence although workers make strategic decisions repeatedly as conditions change, they make them independently at each occasion. This formulation of the problem implies that the game is modelled here as a static game played repeatedly but independently each time. This is not an iterative game as described by Taylor (1976), in which actors would make their current decisions anticipating subsequent decisions of their opponents and calculating the advantages to be derived by choosing strategies that are currently suboptimal. Neither is it a dynamic game, in which the solution is a function of time (Lancaster 1973, and Hoel 1975, 1978) in which actors would commit themselves at a particular time to follow definite strategies in the future. We do not see the problem as a dynamic game because we do not believe that any particular moment can be viewed as a privileged time at which to make a decision binding upon the future. In Lancaster's model the strategies to be chosen by workers and capitalists are the time paths of the wage share and the rate of saving out of profits, and these strategies are chosen once and for all for a finite horizon. What is unreasonable in our view is that in Lancaster's model the horizon is actually approached, and as a result at one moment workers and capitalists rush to consume as if there were no future. We prefer the assumption that every year is the first of the next $h$ years with the view toward which workers and capitalists evaluate their strategies. We do believe, however, that the conflict we describe is in fact an iterative game in which the parameters are subject to trade-offs and are thus endogenous.
}

It then follows that

$$
\Delta P(t)=(s / c-r) P(t),
$$

or

$$
P(t+1)=(1+s / c-r) P(t) .
$$

There are three cases to consider: ${ }^{6}$

If workers choose an $r$ such that $r<s / c$, then wages will grow exponentially, following the exponential growth of profits. In this case we will say that workers are not militant or that they offer wage restraint.

If workers choose an $r$ such that $s / c<r<$ (1 $+s / c)$, then wages will grow rapidly at first and then stagnate at a fixed level as net profits decline to zero. Such a strategy we will call moderately militant.

If workers choose an $r$ such that $r>(1+s / c)$, then workers are highly militant. Wages will then experience a sharp increase as net profits immediately become negative. Since this strategy cannot lead to a compromise, there is no reason to expect that subsequent wages would bear any relation to profits. If they did, wages would oscillate henceforth around a fixed level while profits would oscillate around zero.

One way to review these consequences of the workers' strategies is to observe that the nonmilitant workers would be best off after some time $h_{2}$, about a generation if time is measured in years; moderately militant workers would be best off during the period between some time $h_{1}$ and $h_{2}$; and highly militant workers would be best off during the initial period until $h_{1}$. The values of $h_{1}$ and $h_{2}$ depend upon the particular relation between $r$ and $s / c$. The time span $h_{1}$ can be as short as a couple of years, whereas $h_{2}$ can be as long as thirty years.

In considering the effects of their actions workers cannot be certain, however, that the compromise would hold. Hence, their decision must depend upon the likelihood that capitalists will observe the terms of a compromise if one were to be concluded. Since the future becomes increasingly less predictable the further one looks into it, the wages workers would obtain at each moment in the future would weigh progressively less in the workers' decision, the further in the future they would occur. Hence, we assume that even if

${ }^{6}$ Equation $(10)$ is a first-order linear difference equation of the form $Y(\mathrm{t}+1)=a Y(t)$, with the solution $Y(t)$ $=a^{t} Y(0)$. For any $Y(0)>0, Y(t)$ will be a monotonically increasing function of time if $a>1$; it will monotonically decrease to zero if $0<a<1$; it will oscillate around zero if $a<0$. (Goldberg 1973). 
workers valued wage increases equally regardless of the magnitude of current wages and were indifferent between certain consumption today and certain consumption in the future, they would nevertheless discount the future on the grounds of uncertainty.?

Since we assume below that capitalists also dis-

${ }^{7}$ The assumption that anyone maximizes undiscounted values over infinite horizons is clearly unreasonable. As Ferejohn and Page put it, "The pie-in-thesky quality of the overtaking rule no doubt disqualifies it as a practical decision rule"' (1978, p. 271). count their future welfare on the grounds of uncertainty, we can treat similarly the determinants of risk facing each class. This risk is associated with the political and economic conditions at the time when a decision is made, specifically:

(1) The degree of bilateral monopoly. Unless workers are monopolistically organized, they cannot be certain that particular groups among them would not conclude their own agreements with their respective employers at the cost of other workers. Since capitalists cannot completely avoid competing with one another, each firm faces the danger that other firms would ride free on the

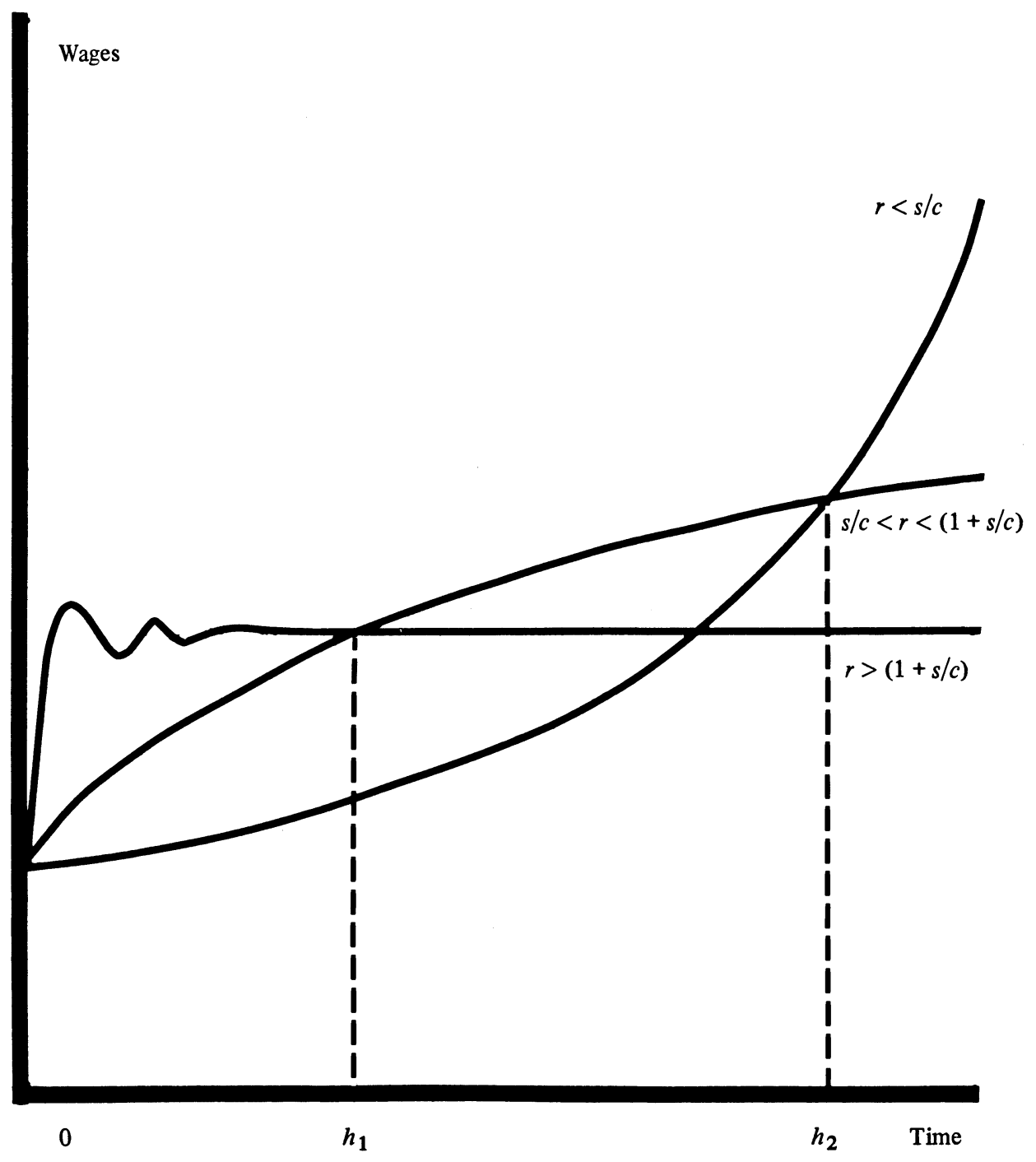

Figure 1 
costs of the compromise. ${ }^{8}$

(2) The institutionalization of labor-capital relations and the likelihood that a compromise would be enforced by the state. The question is whom the state would be capable and willing to coerce to prevent deviations from the compromise: capitalists, workers, or both? Partisan control over the state and the electoral prospects would constitute an important consideration in evaluating this risk.

(3) The ordinary risks inherent in investment owing to domestic and international economic fluctuations, domestic and international competition, technical change, and other economic factors.

Furthermore, the degree of risk born by capitalists when they invest depends in part upon the rigidity of their wage commitment. If wages are highly rigid, capitalists face the risk inherent in investment alone. If the wage bill can be reduced below the terms of the compromise when times are bad, much of the risk is borne by workers. To some degree, therefore, the uncertainty faced by capitalists is inversely related to the uncertainty confronting workers.

Let $a, a>0$, be the rate at which workers discount the future on the grounds of uncertainty. The higher the $a$, the less certain it is at $t=0$ that a compromise would hold in the future and the faster workers discount the future wages stipulated under a compromise. Given the level of wages associated with a particular compromise and the degree of workers' uncertainty, the workers' problem is to find a level of economic militancy that maximizes the current value of their discounted future wages, or

$$
\max _{r} W^{*}=\sum_{t=0}^{t=h}(1+a)^{-t} \hat{W}(t), a>0,
$$

where the anticipated path of wages, $\hat{W}(t)$, is given by equations (8) and (10).'

${ }^{8}$ To discuss this topic, as fundamental as it is, would be to open a can of worms. There are good reasons to believe that workers as well as capitalists are placed by a compromise into a prisoner's dilemma, in which each participant may find it preferable not to pay the costs of the compromise even if such a compromise is collectively optimal for the class. On the other hand, Roemer (1978) argues that workers have no choice but to opt for intra-class solidarity. Edel (1979) relies on a Taylor-like argument about the iterative nature of the prisoner's dilemma. Offe and Wiesenthal (1980) claim that workers can modify each other's preferences in the direction of solidarity by a process of "dialogue." We are skeptical about the validity of these arguments.

${ }^{9}$ Note that workers jolve this problem repeatedly at each $T, T=0,1, \ldots$, and we should have written $W^{*} T$
Note that $W^{*}$ depends upon workers' militancy, $r$, their horizon, $h$, their discount rate, $a$, the productivity of capital, $1 / c$, and the saving behavior of capitalists, $s$. Thus $W^{*}=\mathrm{F}(r ; h, a, c$; $s)$. The productivity of capital, the horizon, and the rate of discount are fixed; they constitute the objective conditions of the moment. The behavior of capitalists with regard to saving is something workers must adjust to. Economic militancy is the strategic variable of workers, whose problem is to choose an $r$ that maximizes $W^{*}$ in the face of the investment strategy of capitalists, represented by $s$. Let $r^{*}(s)$ be the solution of equation (11); that is, the value of $r$ which maximizes $W^{*}$ given that capitalists invest at the rate $s$, when $h, a$, and $c$ are given. Then $r^{*}(s)$ is the best reply strategy of workers (Harsanyi 1977, p. 102).

Workers must weigh the gains of immediate wage increases against the expected gains that would result in the future from less militant demands. Profits appropriated by capitalists who are investing at the rate $s$ will increase output by $s / c$, or $\Delta Y(t) / P(t)=s / c$. Note also that the maximal return to output of a unit of profit, when all profits are invested, is given by the productivity of capital, $1 / c$. We have, then, the following theorem: When the horizon is sufficiently long, workers' best reply will be a compromise level of $r$ if their rate of discount, $a$, is less than the rate of return $s / c$. Otherwise they will be highly militant. Stated formally:

\section{Workers'Best-Reply Theorem}

For all $h>H$, where $H$ is some positive number,

$$
\begin{aligned}
& r^{*}(s)>(1+s / c) \text { if } a>1 / c \text { for any } s, \\
& r^{*}(s)>(1+s / c) \text { if } a>s / c \text { or } s<a c, \\
& r^{*}(s)<(1+s / c) \text { if } a<s / c \text { or } s>a c .
\end{aligned}
$$

In the case of an infinite horizon, the workers best-reply strategy is given by a bangbang function. When $a>s / c$, the workers' best reply is maximal militancy. When $a<s / c$, the workers' best reply approaches zero. (See Appendix for formal proof.)

What occurs when $h$ is some finite number? Our numerical experiments indicate that for $c=$ $4, H$ is approximately equal to 12 ; that is, for any $h>12$, a maximally militant strategy will be best when $a>s / c$ and a compromise strategy will be best when $a<s / c$. (If $h<12$, the

as a sum going from $t=T$ to $t=T+h$. For convenience, we assume that we are examining one such decision, at $T=0$. 
best-reply strategy is to be maximally militant in all cases.) But, for any finite horizon, the workers' best-reply strategy does not suddenly jump from maximal militancy to zero. Rather, for $s>a c, r^{*}(s)$ is a continuous, monotonically decreasing, positive function. The higher the rate of saving above the product $a c$, the lower will be the workers' best-reply level of militancy.

One way to explain this theorem is that workers today would value equally the wages they anticipate receiving in each year of a compromise if for any two successive periods, the compromise wages would grow at such a rate that $W(t+1)=(1+a) W(t)$, or equivalently, $\Delta W(t)=a W(t)$. Now, we know that if a compromise were observed exactly, the wage path would follow the rule $\Delta W(t)=r P(t)$ for all $t$. Hence, the present value to workers who discount the future at the rate $a$ of the wages they would obtain in any period of a compromise characterized by the level of militancy $r$, would be exactly constant if and only if $r P(t)=$ $a W(t)$. The present value of each period's wages would be growing if $r P(t)>a W(t)$; otherwise it would be declining.

Suppose that $r P(t)=a W(t)$ for all $t$. Taking differences of both sides and dividing by $P(t)$ yields $r \Delta P(t) / P(t)=a \Delta W(t) / P(t)$. But $\Delta P(t) / P(t)$ $=(s / c-r)$ and $\Delta W(t) / P(t)=r$. Hence, the present value of future wages stipulated under a compromise would remain constant if $a=(\mathrm{s} / \mathrm{c}$ $-r)$. If $a<(s / c-r)$ or $r<(s / c-a)$, they would be growing over time. If $a>(s / c-r)$ or $r>(s / c-a)$, they would be falling.

Now, if workers are to benefit at all from current profits, $r$ must be positive. The question then is whether there exists, under the conditions given by $s / c$ and $a$, a positive value of $r$ such that the present value of future wages is growing. Such an $r$ exists only if $(s / c-a)>0$, or $s / c>a$. Under these conditions, workers will compromise for any $h>12$. If the horizon is sufficiently long (where the sufficient length depends upon $s / c$ and $a$ ), workers will opt for a strategy of wage restraint such that $r<(s / c-$ $a$ ), since the time path of growing discounted wages will eventually overtake any path of stagnant or declining discounted wages. If, on the other hand, $s / c<a$, then the present value of future wages will decline for any positive $r$ and workers are best off highly militant, with immediate wage increases as large as possible.

The intuitive meaning of this theorem is apparent. Since $s / c$ is the rate of increase of output per unit of profit, it constitutes the maximal rate at which wages could grow under a compromise. If the maximal conceivable growth of wages is lower than the rate at which workers discount their wage increases, then workers will be worse off if they consent to the appropriation of profits. But if output grows faster than workers discount the future; then workers will be better off choosing a strategy of compromise and waiting for future wage gains.

Figure 2 shows some illustrative functions $W^{*}(r, s)$ for $h=30$. The lower segment portrays $W^{*}$ when $a>s / c$ and the upper segment when $a$ $\left\langle s / c\right.$. When $a>s / c, W^{*}$ is a monotonically increasing function of $r$, but when $a<s / c, W^{*}$ has a maximum at a compromise level of militancy.

Figure 3 presents the numerically derived function $r^{*}(s)$, that is, the level of militancy which maximizes $W^{*}$ given workers' risk and the saving behavior of capitalists. As long as $a>$ $1 / c$, this function will be larger than $(1+s / c)$ for all $s$. If we assume $c=4$, then at $a=0.24$, the rate of saving must be as large as 0.96 for the workers' best reply to be a compromise value of $r$; at $a=0.01$, a rate of saving equal to 0.04 will suffice.

These results do not yet constitute a prediction about workers' behavior, however, since the strategies that workers will choose depend upon the behavior of capitalists. Capitalists may be unwilling to increase their rate of saving to levels necessary for a compromise even when one is possible. In fact, capitalists can respond to each threat of workers with a threat of their own: if workers threaten to increase militancy, capitalists may threaten to lower their rate of saving. This, then, is what remains to be investigated.

\section{Capitalists' Strategy}

What would be the objective of capitalists in making compromises with workers? Clearly their chief preoccupation would be to maintain profits as the form in which a part of the product is withheld from current consumption. Yet the defense of the institution of private property is not sufficient: actual profits must be obtained. Furthermore, it seems unreasonable to assume that capitalists are nothing but "rational misers." Ultimately they are concerned not only about being able to reinvest profits but also being able to consume them. Capitalists are not simply workers' investing machines: they do have particularistic interests of their own. It seems reasonable, therefore, to assume that capitalists attempt to maximize their consumption, $C(t)=(1-s) P(t)$, over a period of $h$ years. Moreover capitalists would discount future consumption in accordance with the uncertainty they face. 
If the rate of discount for capitalists is $b$, then the problem faced by capitalists is to choose the value of the rate of saving, $s$, which maximizes the current value of their discounted future consumption given that workers choose the level of militancy, or

$$
\max _{s} C^{*}=(1-s) \sum_{t=0}^{t=h}(1+b)^{-t} \hat{P}(t),
$$

where the anticipated path of compromise profits, $\hat{P}(t)$, is given by $(10)$. The rate of saving, $s$, is the strategic variable of capitalists and $s^{*}(r)$ is their best reply strategy, that is, the value of $s$ that maximizes $C^{*}$ given a particular value of $r$, under conditions given by $h, b$, and c.

The best-reply strategy of capitalists is given by the following theorem. When their horizon is sufficiently long, capitalists' best reply will be to invest as long as the rate at which they discount the future is lower than their return on investment; otherwise they will disinvest. The capitalists' rate of return on investment is equal to the productivity of capital or the increase of output per unit of invested profits, $1 / c$, minus the proportion of this unit of profit paid to workers, $r$. Hence, capitalists will find it best to invest at a positive rate if and only if $b$ $<(1 / c-r)$. Stated formally:

\section{Capitalists' Best-Reply Theorem}

For all $h>H$, where $H$ is the same number as in the workers' best-reply theorem,

$$
\begin{gathered}
s^{*}(r)<0 \text { if } b>1 / c \text { for any } r, \\
s^{*}(r)<0 \text { if } b>(1 / c-r) \text { or } r>(1 / c-b), \\
s^{*}(r)>0 \text { if } b<(1 / c-r) \text { or } r<(1 / c-b) .
\end{gathered}
$$

When the horizon is infinite, capitalists' best-reply strategy is a bang-bang function,

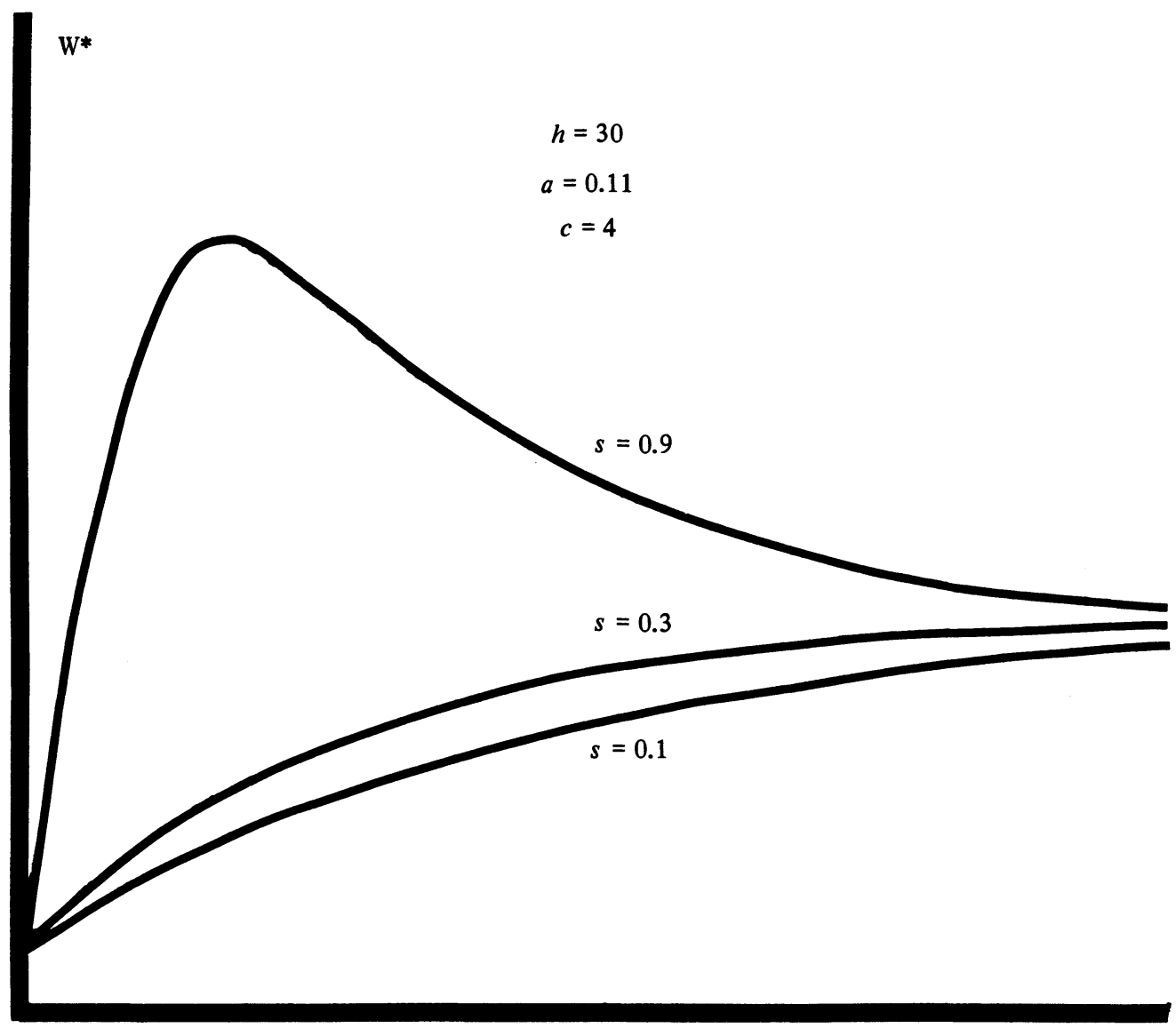


equal to maximal investment or maximal disinvestment according to whether capitalists' discount rate, $b$ is less than or greater than $(1 / c$ $-r$ ). The proof is in the Appendix. For finite horizons, the capitalists' best-reply function must be derived numerically. For $h>12$ (when $c=4), s^{*}(r)$ is a continuous, monotonically decreasing function with $0<s^{*}(r)<1$ when $r$ $<(1 / c-b)$. The greater the restraint of workers' militancy below the quantity $(1 / c-$ $b)$, the higher the best-reply rate of saving by capitalists.

The intuitive meaning of the capitalists' bestreply theorem can be seen as follows. The quantity $(1 / c-r)$ represents the maximal rate at which profits, and therefore consumption from profits, can grow given the level of militancy, $r$, stipulated under a particular compromise. If the maximum conceivable rate of growth of profits is less than the rate at which capitalists discount the future, capitalists are better off disinvesting. But if the maximal possible rate of growth of profits exceeds the capitalists' discount rate, a strategy of positive investment is optimal.

Figure 4 portrays some illustrative functions $C^{*}(s, r)$ for an $h=30, c=4$; Figure 5 shows the positive segment of the function $s^{*}(r)$ under the same conditions.

\section{Conditions of Class Compromise: Basic Results}

Thus far we have examined the best reply of each class to the behavior of the other class, that is, the solution to the maximizing problem facing each class when its opponent behaves in a fixed manner. The best-reply strategy is the optimal strategy if one's opponent is not acting strategically, but both classes do act strategically, and it is only reasonable to assume that each anticipates

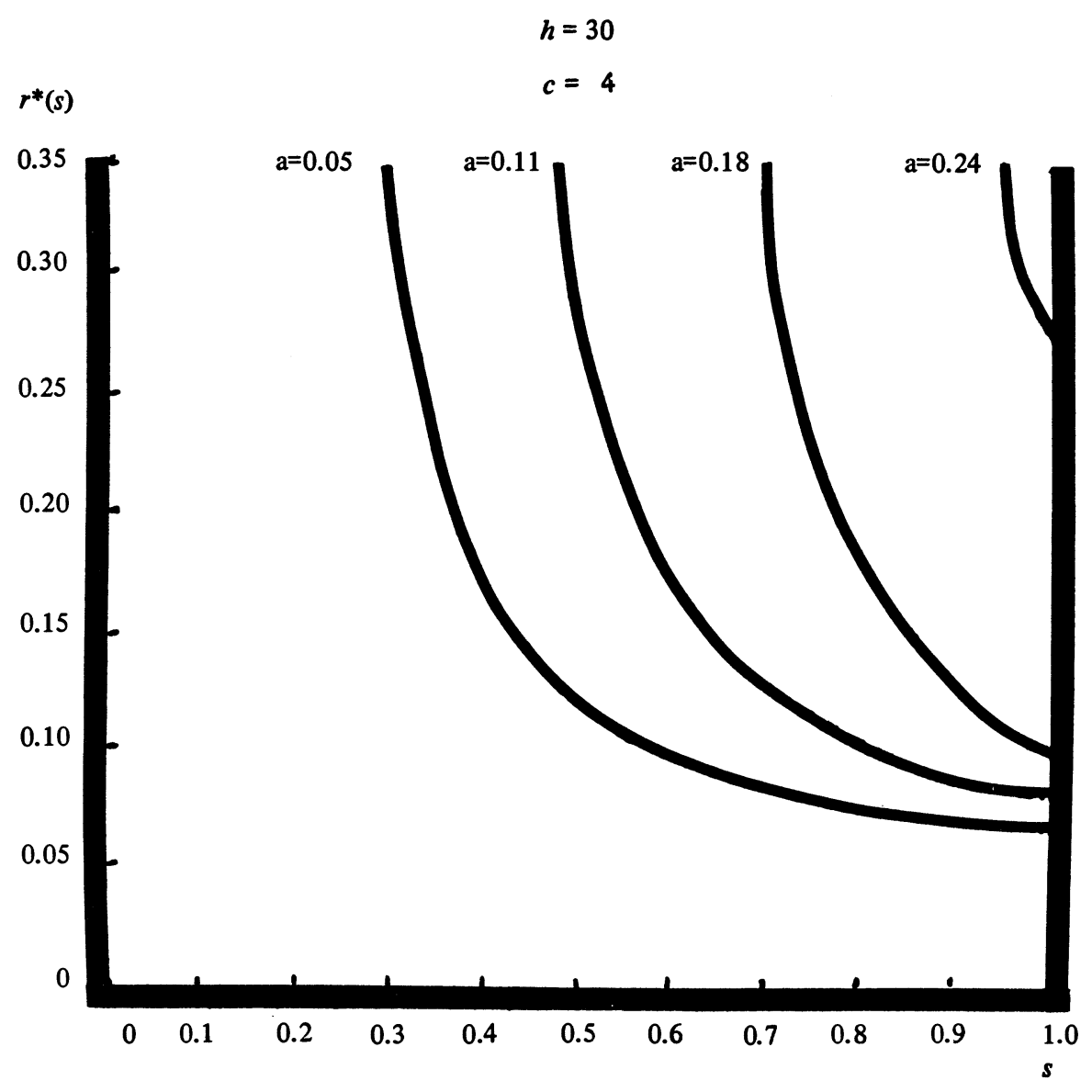

Figure 3 
that the other will behave strategically. Each class must take into account not only the other's actions but also its reactions, not only the other's current strategy but also the likely response to its own choice of strategy. If, for example, workers' best-reply strategy to some positive rate of saving is to become highly militant, they cannot expect capitalists to continue saving if the workers' bestreply strategy is pursued. Workers must take into account that capitalists' best reply to high levels of militancy is to disinvest.

We define a pair of strategies $(r, s)$ to be a solution to the game if neither class could do better with an alternative strategy given the anticipated response of its opponent. Hence, a solution is a pair $(r, s)$ that, once chosen, will be stable as long as conditions remain unchanged. Note that the intersection of the best reply functions $\left(r^{*}\left(s^{*}\right)\right.$, $s^{*}\left(r^{*}\right)$ ) constitutes a solution. Both classes are responding optimally to the current strategy of their opponent. This is the Nash (1954) equilibrium. In our model this solution occurs only when compromise breaks down. ${ }^{10}$ The capitalists' best reply to high levels of militancy is to disinvest, and

${ }^{10}$ There is an exception. In the limiting case when $a=b=0$, there is another Nash equalibrium at a point of compromise.

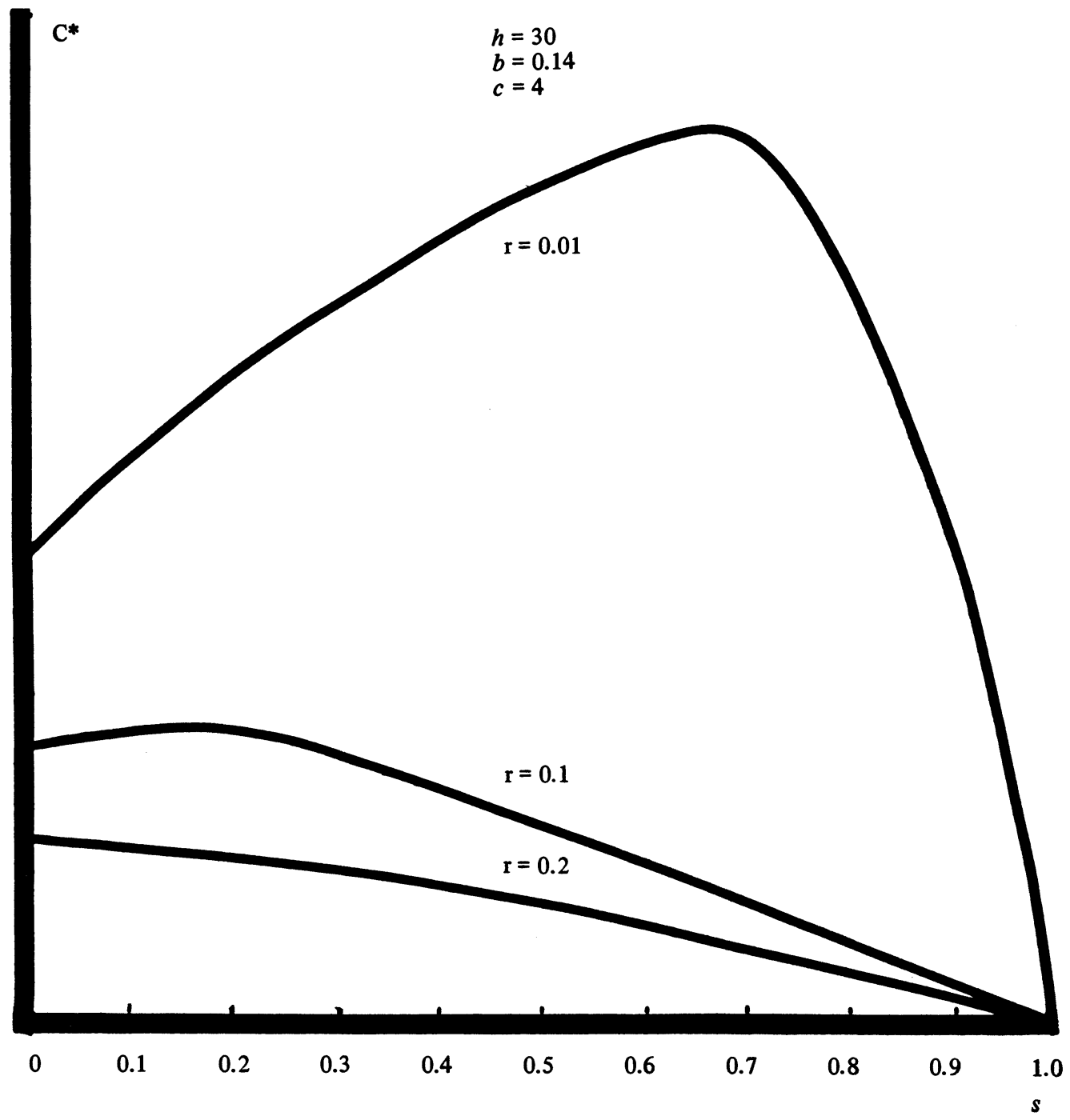

Figure 4 


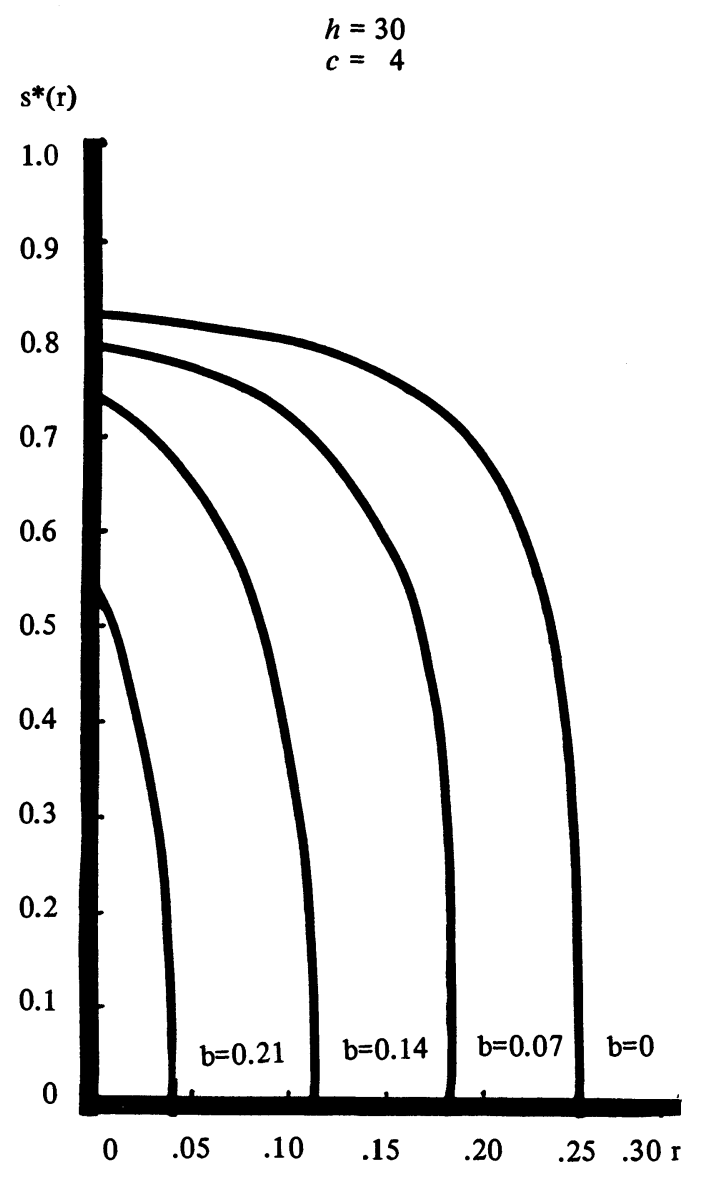

Figure 5

the workers' best reply to disinvestment is to be highly militant.

Suppose, however, that workers anticipate that capitalists will respond to any $r$ with their bestreply strategy $s^{*}(r)$. Now the problem facing workers is to choose the level of militancy which maximizes the function $W^{*}\left(r, s^{*}(r)\right)$, that is, one that maximizes workers' welfare given that capitalists will respond with $s^{*}(r)$ to any $r$ workers might choose. Let this maximizing value of $r$ be $r^{* *}$. The pair $\left(r^{* *}, s^{*}\left(r^{* *}\right)\right)$ is also a solution to the game. The level of militancy $r^{* *}$ is the optimal choice of workers given the anticipated response by capitalists and $s^{*}\left(r^{* *}\right)$ is by definition the capitalists' optimal response to the workers' strategy $r^{* *}$. This is the Stackelberg (1952) solution with workers as the dominant player. Note that $r^{* *}$ is not necessarily in the workers' set of best-reply strategies, $r^{*}(s)$. The function $r^{*}(s)$ is defined as the maximum with respect to $r$ of the function $W^{*}(r, s)$, each value of $s$ constant, whereas the number $r^{* *}$ is defined to be the maximum with respect to $r$ of the function $W^{*}\left(r, s^{*}(r)\right)$, where $s=s^{*}(r)$ is a function of $r$.

Suppose now that it is the capitalists who anticipate that workers will adopt their best-reply strategy $r^{*}(s)$ to any rate of saving, $s$, capitalists choose. Capitalists would then seek to maximize $C^{*}\left(s, r^{*}(s)\right)$. Let the maximizing value of $s$ be $s^{* *}$. The pair of strategies $\left(r^{*}\left(s^{* *}\right), s^{* *}\right)$ is another solution of the game. Given their anticipations of the workers' response, the capitalists have chosen their best strategy, and the workers are responding optimally to the capitalists' choice. This is the Stackelberg solution with capitalists as the dominant player. Again, $s^{* *}$ need not be in the set of capitalists' best-reply strategies. The function $s^{*}(r)$ is the capitalists' best response to the workers' current level of militancy. The number $s^{* *}$ is the capitalists optimal choice given that the workers will respond to any $s$ with their best reply, $r^{*}(s)$.

The Nash equilibrium, which represents absence of compromise, is always possible. What remains to be investigated are the conditions for the existence of compromise, Stackelberg solutions. If the horizon is too short, $h<12$, no compromise solutions exist. For any $h>12$, however, the existence of compromise solutions depends entirely upon the relations between the discount rates $a$ and $b$ and the productivity of capital, $1 / c$. In the subsequent discussion we assume $h>12$. (In the numerical illustrations $h=30$.) There are four cases to consider.

(i) $a>1 / c, b>1 / c$.

Both workers and capitalists face a large degree of uncertainty about whether any compromise would hold. The situation in France in 1936 provides a prototype: in France few workers were organized before 1936, there were almost no traditions of collective bargaining, several unions and parties competed for workers' support, and the very Matignon agreement was concluded under the pressure of spontaneous occupations of factories. Hence neither workers nor capitalists could expect that the agreement would last and, indeed, six weeks after it was concluded both parties began to undermine it: capitalists by dragging their feet in complying with the wage terms (specifically those concerning minimal wages and paid vacations), and by raising prices, and workers by striking and occupying factories again.

Under these circumstances workers find it best to be highly militant regardless of the saving rate chosen by capitalists, whereas capitalists find it optimal to disinvest regardless of workers' militancy. No compromise is possible. All three solutions collapse into one, the Nash equilibrium, at which $r^{*}(s)>1+s / c$ and $s^{*}(r)<0$. 
(ii) $a>1 / c, b<1 / c$.

Workers bear most of the risk, whereas capitalists are relatively certain they would obtain the profits specified by any compromise. This is the case when the degree of unionization is low or several unions compete with each other, capitallabor relations are weakly institutionalized, and workers have little influence over the state. The United States today would provide a prototypical case.

When $b<1 / c$, the best reply strategy of capitalists is to invest at a positive rate as long as workers are not highly militant: $s^{*}(r)>0$ if $r<$ $(1 / c-b)$. The best reply strategy of workers, however, is to increase their militancy regardless of the rate of saving, since $a>1 / c$. One possibility is that workers would follow their best-reply strategy and capitalists would respond by disinvesting, a scenario that ends again without a compromise. But an alternative solution is also possible. Suppose first that for historical reasons workers find themselves in a situation in which they have not been militant in the past and that they begin their current decision-making process by considering a non-militant value of $r$, say $r=r_{0}$. (Consult Figure 6 while following this argument.) If the workers choose $r_{\mathrm{o}}$, then capitalists will choose $s_{\mathrm{o}}$ $=s^{*}\left(r_{\mathrm{o}}\right)$. Since the workers' best reply to any $s$ is to increase their militancy, they will now consider moving to a new level $r=r_{1}$. Capitalists, in turn, will respond to the increase of militancy by lowering the rate of investment to $s_{1}=s^{*}\left(r_{1}\right)$. The effect of the capitalists' adjustment will be to drop workers to a function $W^{*}\left(r, s_{1}\right)$, which is inferior to $W^{*}\left(r, s_{\mathrm{o}}\right)$. If, however, $r_{1}$ is only slightly higher than $r_{\mathrm{o}}$, capitalists will respond (see Figure 5) with a small reduction in their rate of investment, and workers will find that they are better off at the new point $\left(r_{1}, s^{*}\left(r_{1}\right)\right)$ than they were before. Since workers' best reply to $s_{1}$ is again maximal militancy, workers will now consider raising their militancy further to $r=r^{* *}$. Capitalists will lower their rate of saving to $s=s^{*}\left(r^{* *}\right)$, yet workers will still find they are better off at $\left(r^{* *}, s^{*}\left(r^{* *}\right)\right)$ than at any lower value of $r$. Now as the workers consider increasing their militancy past the level $r=r^{* *}$, they discover that the capitalists' best reply is to lower their rate of investment quite sharply, so that workers are worse off at an $r$ slightly higher than $r^{* *}$ than they would be at $r^{* *}$. Even though the workers' best response to any fixed rate of saving, including $s^{*}\left(r^{* *}\right)$, is maximal militancy, the capitalists' threat of disinvestment is effective in the region in which $r$ is somewhat higher than $r^{* *}$. Indeed, the workers discover that if they keep increasing $r$ gradually past $r^{* *}$, they will be successively worse off as $W^{*}\left(r, s^{*}(r)\right)$ keeps decreasing with higher levels of militancy. The threat of dis- investment will not be effective, however, in the entire range of $r>r^{* *}$. As $r$ reaches the value $r=$ $1 / c-b$, capitalists will be disinvesting at the greatest possible rate, and their threat will be exhausted. If workers choose an $r>1 / c-b$, the compromise breaks down, workers seek to nationalize capital stock, and capitalists disinvest. Figure 7 presents a graph of the function $W^{*}\left(r, s^{*}(r)\right)$, which is the array of choices facing workers when capitalists respond according to their best reply. There is a local maximum at $r^{* *}$ which constitutes a compromise solution and a local minimum at $1 / c-b$.

Will the compromise $\left(r^{* *}, s^{*}\left(r^{* *}\right)\right)$ constitute the solution? Unfortunately no answer can be given without additional assumptions. It will be the solution if workers do inherit a situation in which they have not been militant and if a sudden increase of militancy is unfeasible. This is not an unreasonable conjecture. Demands for large wage increases must be pressed through mass actions, strikes, demonstrations. A high level of militancy entails a high level of mobilization, and mobilization is a costly process that requires resources and time. The compromise will also be the solution if workers have good reasons to fear the political consequences of a breakdown of compromise, a topic to which we return below.

$$
\text { (iii) } a<1 / c, b>1 / c \text {. }
$$

Workers are relatively certain to obtain the wages specified by any compromise while capitalists bear the brunt of uncertainty. This would be the case when workers are monopolistically organized, labor-capital relations are institutionalized, and workers are represented by parties that exert electoral influence. The Weimar Republic between 1924 and 1928, Italy between 1969 and 1976, and Great Britain at various times after 1951 would constitute good examples.

When $a<1 / c$, the workers' best-reply strategy is low or moderate militancy as long as the capitalists invest at a sufficient rate: $r^{*}(s)<(1+s / c)$ if $s$ $>a c$. The capitalists' best-reply strategy, however, is to disinvest regardless of the level of militancy. But capitalists must consider the workers' response. Figure $\mathbf{8}$ illustrates the function $C^{*}\left(s, r^{*}(s)\right)$, the anticipated consequence of choosing each positive level of savings given that workers respond according to their best reply. The capitalists' choice is between $s^{*}<0$, that is, disinvestment, which entails a breakdown of compromise (not shown) or the best compromise they can achieve, $s^{* *}$. If the breakdown of compromise is sufficiently dangerous politically to capitalists, the solution $\left.\left(r^{*}\left(s^{* *}\right), s^{* *}\right)\right)$ will be chosen. Given $s^{* *}$, workers reach a global maximum (under capitalism) at $r^{*}\left(s^{* *}\right)$, and this value represents a 
compromise strategy since $s^{* *}>a c$. And for capitalists, the payoff from $s^{* *}$ is the most that can be gained from any compromise.

(iv) $a<1 / c, b<1 / c$.

Both capitalists and workers are quite certain they would obtain what would be expected under any compromise. There is a high degree of bilateral monopoly; capital-labor relations are highly institutionalized; the economy is well situated in the international system. Sweden after 1936 and before the mid-1970s would be a prototype. In Sweden, collective agreements began to be concluded at the turn of the century, and by 1905 a significant proportion of workers was covered by them. These agreements were made binding in a series of decisions by the Supreme Court which first enforced agreements among capitalists and then collective bargains in 1916. In 1920, Labor Courts were established and by 1926 parties could be sued in these courts for unfair bargaining practices. In 1938, a system of collective bargaining was centralized at the countrywide scale, a system that has continued with some modifications up to the present.

In this case, neither the adoption by workers of their best-reply strategy nor by capitalists of theirs would necessarily lead to conflict. Both solutions $-\left(r^{* *}, s^{*}\left(r^{* *}\right)\right)$, where the compromise is enforced by the threat of disinvestment, and $\left(r^{*}\left(s^{* *}\right), s^{* *}\right)$, where it is enforced by the threat of militancyare feasible. Each class would prefer the other to depart from its best-reply strategy. Workers do better threatening capitalists with militancy to the solution $\left(r^{*}\left(s^{* *}\right), s^{* *}\right)$, whereas capitalists are better off threatening workers to the solution $\left(r^{* *}, s^{*}\left(r^{* *}\right)\right)$. The class which is forced to depart

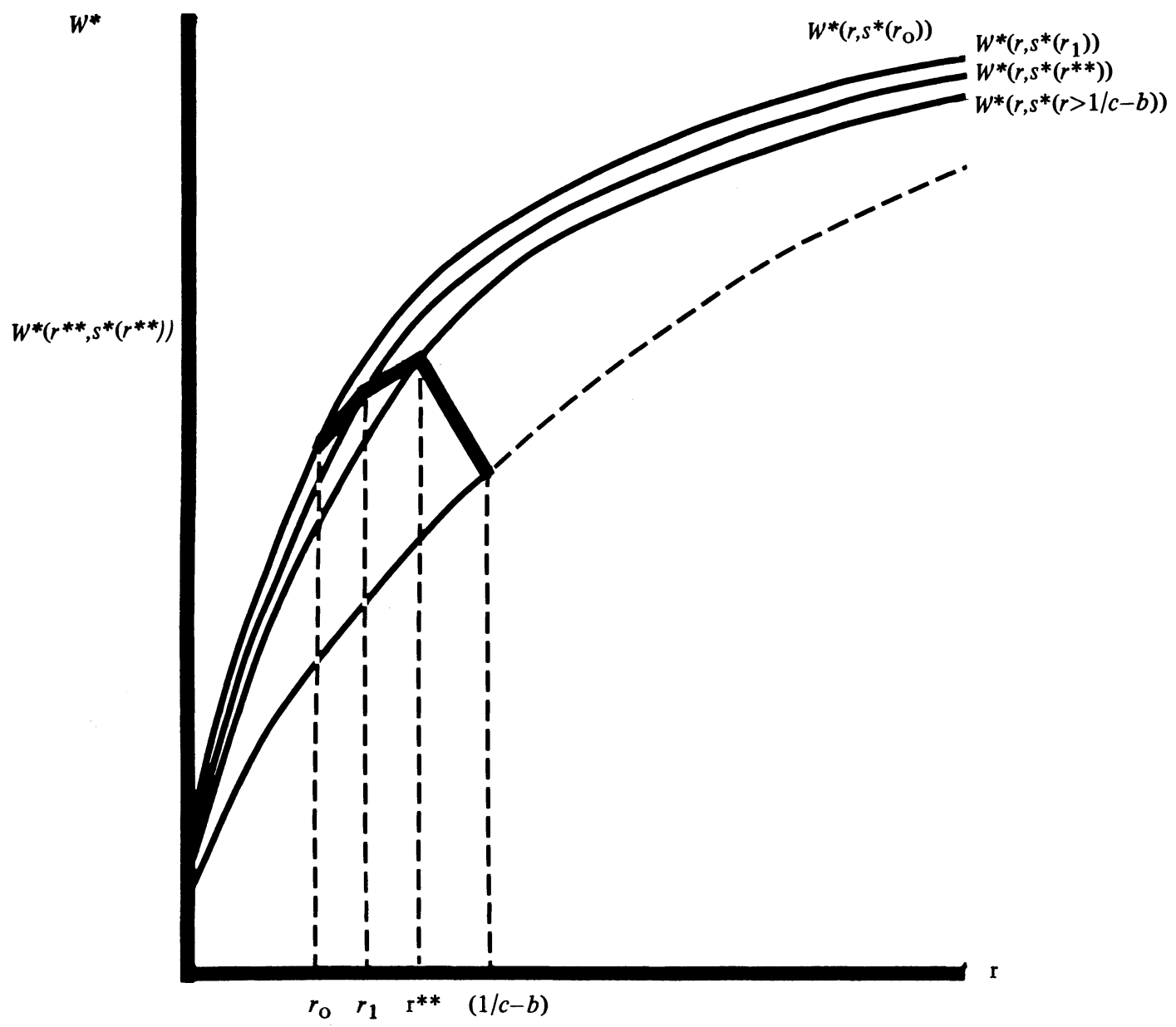

Figure 6 


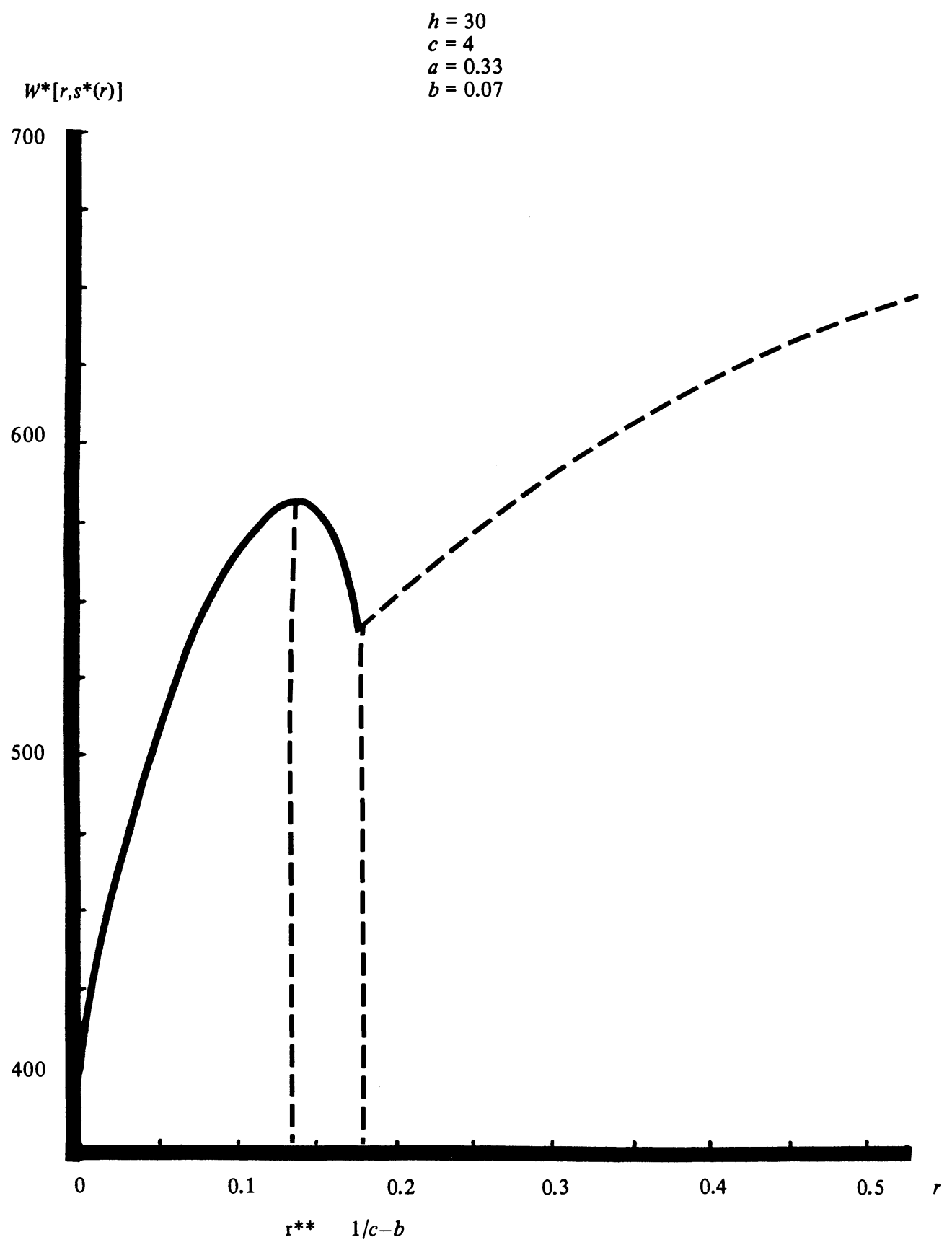

Figure 7 
from its best-reply strategy ends up, in effect, paying the costs of the compromise. If both of the compromise solutions are superior for both players to the outcome that would result if they both obstinately pursued their best-reply strategies, workers and capitalists face a coordination problem (Schelling 1960). We will not pursue this topic further.

Conditions of Class Compromise: An Overview. At this point it is useful to disregard some of the details and summarize the results.

When both classes are highly uncertain about whether a compromise would hold, a compromise cannot be established. Workers become highly militant, regardless of the rate of saving, and capitalists seek to disinvest, regardless of militancy.

When workers are highly uncertain and capitalists relatively certain, a compromise may be established at a point at which workers are kept from increasing their militancy by capitalists' threat of disinvestment, whereas capitalists' optimal rate of investment is positive.

When the workers are relatively certain and the capitalists bear high risk, a compromise may be

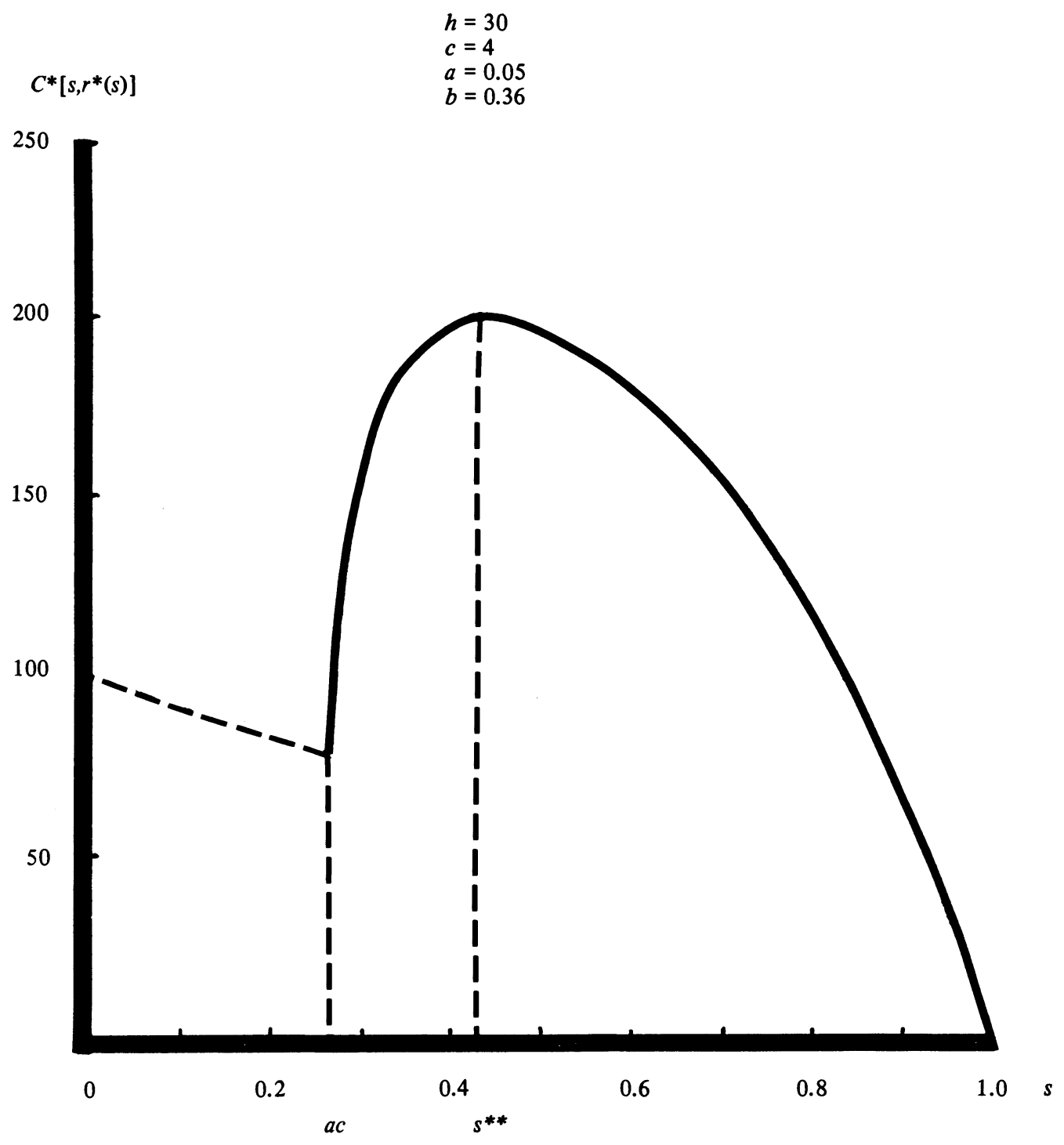

Figure 8 
Table 1. Illustrative Results

$h=30,1 / c=0.25,1 /(1+a)(1+b)=0.7 \uparrow$

\begin{tabular}{|c|c|c|c|c|c|c|c|c|c|c|}
\hline \multirow[b]{2}{*}{$a$} & \multirow[b]{2}{*}{$b$} & \multicolumn{4}{|c|}{ Workers Dominant } & \multicolumn{4}{|c|}{ Capitalists Dominant } & \multirow[b]{2}{*}{ Comments } \\
\hline & & $r^{* *}$ & $s^{*}$ & $W^{*}$ & $C^{*}$ & $r^{*}$ & $s^{* *}$ & $W^{*}$ & $C^{*}$ & \\
\hline $\begin{array}{l}0.43 \\
0.35\end{array}$ & $\begin{array}{l}0.00 \\
0.05\end{array}$ & $\begin{array}{l}.215 \\
.160\end{array}$ & $\begin{array}{l}.655 \\
.615\end{array}$ & $\begin{array}{l}483 \\
557\end{array}$ & $\begin{array}{l}541 \\
548\end{array}$ & & & & & $\begin{array}{l}r>s / c \\
r>s / c\end{array}$ \\
\hline $\begin{array}{c}0.33 \\
1 / c \\
0.23 \\
0.16 \\
0.15 \\
0.10\end{array}$ & $\begin{array}{c}0.08 \\
0.15 \\
0.16 \\
0.23 \\
1 / c \\
0.30\end{array}$ & $\begin{array}{l}.150 \\
.080 \\
.070 \\
.015\end{array}$ & $\begin{array}{l}.585 \\
.540 \\
.505 \\
.225\end{array}$ & $\begin{array}{l}578 \\
701 \\
726 \\
787\end{array}$ & $\begin{array}{l}529 \\
548 \\
534 \\
505\end{array}$ & $\begin{array}{l}.285 \\
.165 \\
.165 \\
.140\end{array}$ & $\begin{array}{l}.960 \\
.765 \\
.715 \\
.580\end{array}$ & $\begin{array}{l}1058 \\
1501 \\
1611 \\
2325\end{array}$ & $\begin{array}{r}23 \\
142 \\
154 \\
185\end{array}$ & $\begin{array}{l}r<s / c \\
r<s / c \\
\\
r<s / c \\
r<s / c\end{array}$ \\
\hline $\begin{array}{l}0.09 \\
0.00\end{array}$ & $\begin{array}{l}0.32 \\
0.43\end{array}$ & & & & & $\begin{array}{l}.140 \\
.140\end{array}$ & $\begin{array}{l}.540 \\
.290\end{array}$ & $\begin{array}{l}2556 \\
6809\end{array}$ & $\begin{array}{l}189 \\
204\end{array}$ & $\begin{array}{l}r>s / c \\
r>s / c\end{array}$ \\
\hline $\begin{array}{l}0.43 \\
0.00\end{array}$ & $\begin{array}{l}0.43 \\
0.00\end{array}$ & $\begin{array}{l}\text { no cor } \\
.060\end{array}$ & $\begin{array}{l}\text { omise } \\
.810\end{array}$ & $\begin{array}{l}\text { lution } \\
19867\end{array}$ & $\begin{array}{l}\text { xist } \\
10023\end{array}$ & .060 & .810 & 19867 & 10023 & $\begin{array}{c}r>1+s / c \\
r<s / c\end{array}$ \\
\hline
\end{tabular}

$\lceil$ Except the last two rows for which $a=b$.

concluded at a point at which the capitalists are forced to save by the threat of militancy, whereas the workers' optimal level of militancy is not high.

When the workers and capitalists both face only moderate amounts of uncertainty, both a compromise concluded under the capitalists' threat of disinvestment and one reached under workers' threat of militancy are feasible. Either may be concluded.

For reference, some illustrative results are summarized in Table 1, for $h=30$ and $c=4$. Most entries in this table are obtained on the condition that class-specific discount rates are inversely related according to the equation $(1+a)^{-1}(1+b)^{-1}=$ 0.7 .

Supposing that compromises are concluded in the manner specified by our analysis, the question arises whether or not the outcomes reached will be efficient in the Pareto sense. (See Schelling 1977, for a general treatment of Pareto efficiency of $n$-person game equilbria.) The concept of the solution we have been using is essentially a noncooperative one, since we have assumed that although workers and capitalists may choose their strategies in anticipation of the best reply of the opponent, they nevertheless choose these strategies independently rather than jointly. In fact, they need not negotiate at all: each class selects its optimal strategy and no negotiation need be involved. This is important since this concept of the solution means that the model does not presuppose the existence of any corporatist or consociational institutions that would involve direct negotiations. The model is general for all situations in which there is a fair degree of bilateral monopoly, even if all this means is that workers have only the right to associate and to strike, without any further relations with capitalists. But if the solutions obtained in this fashion are highly inefficient, that is, if workers and capitalists can simultaneously improve on these solutions by engaging in direct negotiations, then one would expect that corporatist arrangements must constitute an integral part of any compromise.

Numerical analysis indicates that the set of points that are Pareto superior to the equilibrium solutions is rather small; that is, that the room for improvement over the non-cooperative solutions is limited. Moreover, such an improvement is insignificant when compared with even a minute change in certainty. Workers are better off with a non-cooperative solution at $a=0.30$ than with the best of the Pareto superior points to the noncooperative solution at $a=0.33$. They are better off with a non-cooperative solution at $a=0.04$ than the best cooperative solution at $a=0.05$. Hence, workers are better off struggling to increase their certainty that a compromise would hold rather than seeking to improve the terms of a less certain compromise. They are better off competing for political power than making deals with capitalists. Clearly the model does not preclude direct negotiations. Since, however, the noncooperative solutions are not far from the Pareto efficient frontier, it would be wrong to expect that class compromise can occur only in the presence of institutional arrangements that involve direct negotiations.

Note, however, a major limitation of this model. We treat the political arrangements that determine the class differential risks and consequently rates of discount as the given conditions of the moment when decisions are made. These arrangements may change in time, but such 
change is exogeneous to our model. All we say is that when conditions change, strategies will change as well, but our assumptions do not permit the players to trade off material gains for political power, that is, for a greater probability that class interests will be realized to a particular degree. (This is the definition of political power of Poulantzas 1973.) A more complicated model would treat the class differential rates of discount as endogeneous to the conflict and would allow such trades of material gains for greater certainty. Hence, to the extent to which corporatist arrangements can simultaneouslly increase the certainty of both classes, such arrangements will yield significantly superior outcomes.

More generally, note that although we assume that a particular compromise is reproduced over time if and only if the conditions $a, b$, and $c$ under which it was originally arrived at remain the same, compromises break down in our model only for exogeneous reasons. These reasons include a change of the political situation, characterized by $a$ and $b$, and the change of the economic structure, characterized by $1 / c$. Any change in the relation between class-specific discount rates and the productivity of capital will alter the structure of conflict and the solution associated with it. One instance of such change may be the exhaustion of the easy import substitution industrialization (O'Donnell 1973). Suppose that in a particular country workers enjoyed sufficient certainty, capitalists faced high risk, and a compromise was reached at the point where capitalists are threatened by militancy: $a<1 / c, b>1 / c$, $\left(r^{*}\left(s^{* *}\right)\right.$, $\left.s^{* *}\right)$. Suppose now that to continue the process of industrialization a large and lumpy investment must take place. This will mean that the capitalto-output ratio, $c$, will have to be increased temporarily, as capital stock is being amassed without the corresponding increase in output. It is then possible that $1 / c$ will fall below the value of $a$ and the compromise will break down. Faced with militant workers, capitalists may seek protection under an authoritarian regime.

Another source of exogenous change may originate from those workers or capitalists or both who are excluded from the compromise. Indeed, no compromise ever includes all workers and all capitalists, and at some stage those excluded from it may gather sufficient political strength to alter the terms of a compromise. This is what happened in several waves of rapid unionization of industrial workers, a good example being the United States in the 1930s.

Note that although the compromise solutions do not depend upon the initial conditions $W(0)$ and $P(0)$, there is one kind of compromise which threatens capitalists in the long run. For all finite horizons there exist values of $a$ and $b$ at which the compromise will be concluded with workers being moderately militant, that is, with $r>s / c$. In such cases profits decline exponentially to zero, and so does the rate of profit. Inspection of Table 1 shows that when $h=30$ and $(1+a)^{-1}(1+b)^{-1}=$ 0.7 , workers may be moderately militant at the solution when $a>0.33$ or $a<0.09$. Thus, under such conditions the compromise leads to what has been described as "the profit squeeze" (Glyn and Sutcliffe 1972): a wage-induced secular fall of the rate of profit. The existence of a compromise does not preclude, therefore, the possibility that profits are falling.

Finally, reflecting upon the results we must reexamine the very concept of a compromise. At the outset, we have defined a compromise as a situation in which workers pursue strategies that entail positive profits, and capitalists consent to institutions that enable workers to pursue their claims with a reasonable chance of success. This definition was thus limited to the distributional aspect of class conflict. Yet as one would expect, we discovered in the course of analysis that any class compromise must also include a central feature of the process of production, namely the rate of investment out of profit. A compromise is thus a situation in which both workers and capitalists moderate their distributional claims, and capitalists choose a high rate of saving.

The rate of saving is an intrinsic feature of any compromise. An agreement concerning the rate of transformation of profits into wages would be too tenuous from the worker's point of view because it would leave open the question of whether capitalists would save and invest enough to make wage increases possible. The perennial complaint of the working-class movements is that capitalists are too lazy or too inefficient to be entrusted with the control over investment. Already in 1910 a French socialist noted the "timidity," the "uncertainty," the "lack of initiative" of capitalists. "We ask French employers," he continued, "to resemble the American employer class.... We want a busy, active, humming country, a veritable beehive always awake. In that way our own force will be increased"' (Griffuelhes 1910, p. 331). And again, in 1975 , Chiaramonte $(1975$, p. 31) complained in an official report to the Central Committee of the Italian Communist Party about a "disconcerting lack of ideas on the economic and industrial future of the country and on the productive prospects for their (capitalists') own industries. They continue to cling to productive, technical, and organizational policies adopted several dozen years ago. ...."

Investment cannot be left to the control of capitalists: this is an essential feature of any compromise. Having announced the austerity policy, having repeated that the P.C.I. is "not aiming at a 
worsening of the situation, . . . on an aggravation of the crisis," Chiaramonte continued immediately that "this does not mean that we in any way think it would be sufficient to limit the workers' pay claims and demands for greater control over working conditions to automatically obtain an increase in investment and productive reconversion" $(1975$, p. 34). What the P.C.I. demands in exchange for austerity is control over investment. Or, as the 1973 Conference of the Irish T.U.C. put it, "all workers must be guaranteed that their wage restraint will lead to productive and beneficial investment and not towards even further increases in the personal incomes of the privileged section of society. . . ." (Cited in Jacobsen 1980, p. 268).

\section{Beyond Capitalist Democracy}

What is the alternative to class compromise? We have referred to the breakdown of compromise without specifying what might occur in its stead. Indeed, our results concerning the conditions of class compromise are ultimately unsatisfying in that they are inconclusive. The decision to compromise depends, in the end, on a comparison of the best compromise that can be obtained with the consequences of no compromise. The question of the balance of political power becomes paramount; the outcome highly uncertain. We believe that any analysis based upon rational calculations of expected benefits is of limited value in moments of crisis. Conflicts are inherently laden with uncertainty, and this uncertainty is difficult to evaluate, not only for us but also for the protagonists of our story. Nevertheless we will seek to elucidate the choice that is involved in considering the transition to socialism as an alternative to either compromise or economic militancy under capitalism.

First let us clarify the outcomes that may occur in the absence of compromise. Generically, these are threefold.

(1) Workers have the political power to nationalize the means of production and to organize accumulation on a new basis. Profit is abolished as an economic and legal category and capitalism with it.

(2) Capitalists have the political power to impose a non-democratic solution. Recent experiences of Brazil, Chile, and Argentina demonstrate that profits grow under such regimes simultaneously with a dramatic fall in wages. Economic deprivation of workers as well as widespread physical repression are the hallmark of authoritarian regimes.

(3) Capitalists do not have the power to impose an authoritarian solutiun nor workers to impose socialism. In this case, the democratic capitalist system continues without compromise but rather with an uneasy stalemate, a prolonged "catastrophic" crisis described by Gramsci (1971, p. 210ff) with specific reference to the MacDonald government in Great Britain. This was perhaps the situation in several Western European countries after the defeats of general strikes fought on economic issues: Sweden in 1909, Norway in 1921, France in 1920, Great Britain in 1926. This may also be the situation in Great Britain today. These situations are characterized by high strike intensity and a fair amount of repression: they constitute a tug-of-war. Wages and profits oscillate sharply.

We will not investigate these alternatives any further but only specify the structure of choice involved in considering the socialist alternative. How would workers choose a strategy of transition to socialism? We will outline only a framework for such an analysis but will stop short of providing the analysis.

Note first that workers may embark upon the strategy of socializing the capital stock under two distinct conditions. The first has been described: compromise is impossible, workers make economic demands, provoke a political crisis, and in this crisis the only choice may come to be between socialism and authoritarian capitalism. This scenario, in which the transition to socialism originates from an economic crisis under capitalism, is the one typically envisaged by Marxists as the road to socialism. This is a scenario that leads to the politique de pire: in this view, the worse the economic situation under capitalism, the more likely socialism becomes. We are persuaded that this strategy of crisis mongering is unfeasible and irresponsible. As Varga warned in 1927, "If the working class creates conditions in which the profits of capitalists become impossible but at the same time the bourgeoisie is not defeated politically and the doctrine of the proletariat has not been established, the bourgeoisie, by means of implacable terror, crushes the working class in order to maintain the economic basis of the capitalist system and make possible the exploitation of labor" (Pirker 1965, pp. 133-4; translated by David Abraham).

Workers may, however, find socialism to be the attractive alternative under the same conditions under which they can conclude an attractive compromise under capitalism. If workers have political power that enables them to enforce compromises under capitalism, would they not use this power to transform the society into socialism? If socialism is preferable under the same conditions under which workers are able to conclude a compromise under capitalism, no compromise would ever be concluded by rational workers. Hence, the conditions of capitalist compromise must always 
include the superiority of such a compromise to the socialist alternative.

Let us speculate about the following scenario. Suppose that at some time $t=0$ workers decide to nationalize the entire capital stock. At some later time $t=T$ the final nationalization bill is passed and the entire capital stock is socialized. During the remaining period, from $t=T$ to $t=h$, the institution of profit no longer exists and investment decisions are made by the entire society through some reasonable voting mechanism.

During the period $0 \leqslant t<T$, that is, until socialization is complete, the private ownership of capital remains intact. Faced with imminent nationalization, capitalists will disinvest as rapidly as possible. They cannot be prevented from disinvesting, and they cannot be taken by surprise: even Lange (1938), the foremost advocate of the "one stroke" nationalization strategy, admitted that some disinvestment would occur before capital stock is nationalized. Let $S^{*}(T)$ be the current value of discounted wages between $t=0$ and $t=T$ when workers pursue a strategy of socialization and capitalists respond by disinvesting. It is likely that $S^{*}(T)$ will not be the most that workers could obtain between $t=0$ and $t=T$. If $W^{*}(T)$ is the best they could do under capitalism, then the difference between these quantities is the cost of the transition strategy during this period.

At $t=T$ the capital stock becomes entirely nationalized and henceforth the economy operates in the following manner. The entire society now joins in the program of determining the optimal rate of saving out of total output, $s_{w}$, and the volume of investment is given by $\Delta K(t)=s_{w} Y(t){ }^{11}$ Let $q$ be the risk inherent in investment facing the socialist society. Then the problem to be solved would be:

$$
\begin{aligned}
& \max _{s_{w}} S^{*}=\left(1-s_{w}\right) Y(T) \sum_{t=T}^{t=h}(1+q)^{-(t-T)} \\
& \quad\left(1+s_{w} / c\right)^{(t-T)} .
\end{aligned}
$$

Let the rate of saving which solves this problem be $s^{*}$, and the resulting welfare of workers under socialism be $S^{*}(h-T)$.

The total value of socialism to workers making a strategic choice at $t=0$ would also depend, however, upon the risk that the socialist transition would be aborted or subverted under the pressure

\footnotetext{
${ }^{11}$ We hope that the reader will not mistake this model of socialism for a description of the Soviet Union or other Eastern European countries. In those countries investment decisions arise out of a game between central planners and managers, with a known effect of investing at a level higher than the preference of the population.
}

of the armed forces, foreign governments, foreign firms, or even by the workers themselves, if they object to the costs that have to be borne during the period $0 \leqslant t<T$. (See Kolm 1977 for some of these considerations.) Even if a nationalization law is passed by a parliament in accordance with all of the constitutional requirements, capitalists have numerous ways to fight back. If the probability that the socialist transition would be accomplished is $(1-f)$ and the probability that the final outcome would be a capitalist dictatorship is $f$, then we can think of $k S^{*}(h-T), k<1$, as the expected value of the revolutionary attempt, where $k S^{*}(h-T)=(1-f) S^{*}(h-T)+f$ (material welfare under capitalist dictatorship). Note that $k$ is likely to be closer to unity the greater the proportion of the capital stock is already publicly owned and the greater the electoral strength of the socialist parties.

The total value of pursuing a strategy of transition to socialism to workers at $t=0$ can be thus thought of as: $S^{*}=S^{*}(T)+k S^{*}(h-T)$, where $S^{*}(T)$ and $S^{*}(h-T)$ are as given above. Note that this is again the current value of the socialist transition to workers at $t=0$ when they decide whether or not to embark on this road. Hence, this value would be compared to the best workers can do under the particular conditions of democratic capitalism, $W^{*}(r, s)$, where $(r, s)$ represents either a compromise or a tug-of-war. ${ }^{12}$

As we forewarned, we will not carry this discussion any further, mainly because we believe that this calculation involves too many imponderables to be taken seriously in practice. We wanted to clarify the nature of this decision, but we do not

\footnotetext{
${ }^{12}$ Note some assumptions implicit in this formulation. First, we assume that workers living under capitalism evaluate socialism in the same terms as they do capitalism. Second, we assume that socialism is only as efficient as capitalism in allocating resources to uses: in our formalism, $c$ remains the same after nationalization. Finally, we assume that workers compare their best possible, not their current, outcome under capitalism with socialism. The first of these assumptions would be rejected by those who maintain, with Heller (1975), that if socialism is to be preferable it is because it would satisfy needs other than those experienced by workers under capitalism. The second assumption would be rejected by the entire socialist tradition, which always maintained that socialism would be a more efficient, not only more just, system for satisfying material needs. Both of these assumptions should perhaps be rejected, but then the choice of socialism would be unproblematic. In turn, the last assumption is necessary to make the problem reasonable. Roemer (1982), for example, does not give workers a chance to improve their conditions under capitalism, whereas we did not give them a chance to opt for socialism in an earlier version of this paper.
} 
intend this to be a description of how the decisions to embark or not to embark upon the socialist path are in fact made.

\section{Class Conflict and the State}

Suppose for a moment, as did Marx, that the conflict over material interests is irreconcilable and that workers' pursuit of material interests leads them inevitably to the realization that these interests can be advanced if and only if the institution of profit is abolished altogether. Given this assumption, the reproduction of capitalist relations becomes problematic. Even if all the conditions for expanded reproduction of capital are fulfilled "of itself," "by the mere repetition of isolated acts of production" (Marx 1967, Vol. I, pp. 577-8), the survival of capitalist relation is no longer guaranteed when workers organize collectively to abolish them. One must then look beyond the system of production for the mechanisms by which capitalism is maintained. Hence a functionalist account of capitalist reproduction follows necessarily from this model of class conflict. For, if an irreconcilable conflict over the realization of material interests is characteristic of any capitalist society and if capitalism withstood this conflict during at least one hundred years, then some mechanisms external to class relations must be evoked to explain this durability. Whenever class conflict happens to generate a threat to the reproduction of capitalist relations, some mechanism, most often thought to be the state, must come to the rescue by repressing, organizing ideological domination, or coopting.

The gradual rejection of instrumentalist theories of the state (Miliband 1969) and their replacement by a model in which the state is viewed as relatively autonomous from class relations did not alter this functional logic. In the instrumentalist version, the state was acting predictably in defense of the interests of capitalists because it was directly populated by capitalists or like-capitalists. In the structuralist version, the state is seen as autonomous from particularistic interests of capitalists and as based on popular support: "the popular class state"' (Poulantzas 1973). Yet somehow this state still manages to repress, to organize ideological domination, and to intervene where and when needed in ways designed to and having the effect of maintaining capitalism in the face of conflicts. Both the instrumentalist and autonomous theories of the state are functionalist theories, and although the instrumentalist theory is clearly at odds with the facts, it has at least the logical virtue of explaining why the state-concrete people functioning in concrete institutionsdoes all that is necessary to reproduce capitalist relations.
In fact, ultimately even the state as an institution disappears from this functionalist analysis. Since, by assumption, the state invariably responds to the functional requirements of capitalist reproduction and since its policies have, by assumption, the function of fulfilling these requirements, one can proceed from requirements to reproduction without bothering with the state at all. The very concept of the state is based on a reification. The state is ready-to-wear; it is tailored before class conflicts, as if in anticipation of those conflicts, appearing fully clothed whenever these conflicts threaten the reproduction of capitalist relations. The state is always given, already in its functional garb, before any conflicts occur, before any problems call for resolution.

Indeed, the perennial difficulty of any functionalist perspective is to account for the reasons why conflicts among specific groups under concrete historical circumstances would regularly result in the state performing its functions. It is quite true that once the manner in which a society responds to variations of historical conditions has been institutionalized, much of this response is automatic. To put it differently, each society organizes the mechanisms of its reproduction as a system. Yet it is equally apparent that the activity of institutions and the institutions themselves are the continual outcome of conflicts. Under concrete historical circumstances, particular groups enter into conflicts over particular issues, and the outcome of these conflicts is a particular organization and a specific set of policies of the state. What is not clear is why this policy would be predictably one that would have the function of reproducing capitalist relations. Clearly the answer to this question cannot be that the state reproduces capitalist relations because this "is" its function. This answer can be twofold: either the capitalist system is organized in such a manner that it is reproduced regardless of all conflicts, and then these conflicts, including class conflict, acquire the status of a superfluous ritual, as in Sahlins, or outcomes of conflicts do in fact determine the policies that the state pursues, in which case the burden of explanation is shifted to these conflicts and any concept of function becomes redundant.

These problems-an implausible account of reproduction, the inability to explain why the state pursues particular policies, and the reification of the state-are inherent in any functionalist perspective. Our claim, however, is that this perspective is made necessary by an incorrect model of class conflict in democratic capitalist societies. The very problem of reproduction appears as a functional one because the model of irreconcilable class conflict leads to the conclusion that capitalism could not have survived as a choice of 
the working class. Indeed, the working class appears in this model as a passive victim of repression, a perpetual dupe of ideological domination, or, at best, as repeatedly betrayed by its leadership.

If our model of class conflict is valid, then the need for this kind of a construction disappears. The policies pursued by the state in capitalist societies-the policies designed to invigorate and strengthen the capitalist system of social organization-are no longer viewed as functions of an autonomous state facing the threat of a revolutionary working class. These policies-and the state itself-now appear as an expression of a compromise: they are quite instrumental with regard to the interests of a class coalition that includes both capitalists and organized workers. When workers pursue strategies that lead to a compromise, the state does what appears necessary to reproduce capitalism because this is the choice of the workers as well as the capitalists. The organization of the state as an institution and the policies pursued by this institution constitute an expression of a specific class compromise.

Class compromise implies a particular organization of political relations, a particular relation between each class and the state, a particular set of institutions, and a particular set of policies. The state must enforce the compliance of both classes with the terms of each compromise and protect those segments of each class that enter into a compromise from non-cooperative behavior of their fellow class members. The state must induce individual capitalists to make the decisions required by the class compromise, shifting the terms of choice which they confront to produce the requisite aggregate effects as capitalists compete with each other. Finally, since the state of class compromise is a democratic state, it must see to it that the class coalition that forms the compromise can win popular support in elections, which implies that interests of those excluded from the particular coalition must also be taken into account. All of these indications lead, therefore, to the kind of a state that was envisioned by Keynes when he claimed that "It is not the ownership of the instruments of production which it is important for the State to assume. If the State is able to determine the aggregate amount of resources devoted to augmenting the instruments and the basic rate of reward to those who own them, it will have accomplished all that is necessary" (1936, p. 378). Necessary, that is, to organize class compromise.

\section{Appendix}

In this Appendix we prove the best reply theorems of workers and capitalists for the case in which the horizon is infinite. To restate what is to be proven: when $h \rightarrow \infty$, the workers' best-reply strategy is given by the function $r^{*}(s)$, where

$r^{*}(s)>(1+s / c)$ when $a>s / c$ or $s<a c$, $r^{*}(s) \rightarrow 0$ when $a<s / c$ or $s>a c$,

and the capitalists' best-reply strategy is given by the function $s^{*}(r)$, where

$s^{*}(r)<0$ when $b>(1 / c-r)$ or $r>(1 / c-b)$, $s^{*}(r) \rightarrow 1$ when $b<(1 / c-r)$ or $r<(1 / c-b)$.

Since the math is less cumbersome, let us begin with the capitalists' best-reply function. From equation (10) in the text, we can write

$$
P(t)=P(0)(g-r)^{t}, \text { where } g=(1+s / c) .
$$

Substituting this expression for $P(t)$ into equation (12), expanding the geometric series, and rearranging the terms yields:

$$
\begin{aligned}
C^{*} & =-\frac{(1+b)(1-s) P(0)}{(s / c-(b+r))}+ \\
& +\frac{(1+b)(1-s) P(0)}{(s / c-(b+r))}\left[\frac{g-r}{1+b}\right]^{h+1}
\end{aligned}
$$

Consider first the case in which $b>(1 / c-$ $r)$. Since $s \leqslant 1$, it follows that $(1+b)>(1+s / c$ - $r)$ or $(g-r) /(1+b)<1$. Therefore, as $h$ approaches infinity, the second term vanishes. The derivative of the first term with respect to $s$ is

$$
\frac{\partial C^{*}}{\partial s}=\frac{(1 / c-(b+r))(1+b) P(0)}{(s / c-(b+r))^{2}} .
$$

Since $1 / c-(b+r)<0$ by hypothesis, this derivative is always negative, and capitalists will disinvest.

Suppose now that $b<(1 / c-r)$, which is possible only if $1 / c>b$. This presents capitalists with the following choice. If they choose an $s$ such that $s / c<(b+r)$, then $(g-r) /(1+b)<$ 1 , the second term vanishes, and $C^{*}$ is bounded above for all $h$. If, on the other hand, capitalists choose an $s$ such that $s / c>(b+r)$, then $(g-$ $r) /(1+b)>1$, from which it follows that the final term is positive and grows without bound as $h$ increases. If $h$ is sufficiently large, the latter choice will be superior. Now, as $h$ approaches infinity, the function $C^{*}$ is domi- 
nated by the second term of (A2). Taking its derivative with respect to $s$ :

$$
\frac{\partial C^{*}}{\partial s}=\left\{\frac{\partial B}{\partial s}\left[\frac{g-r}{1+b}\right]+\frac{B(h+1)}{c(1+b)}\right\}\left[\frac{g-r}{1+b}\right]^{h}
$$

where

$$
B=\frac{(1+b)(1-s) P(0)}{[s / c-(b+r)]} .
$$

Since $s / c>(b+r), B>0$ and the second term inside the brackets is positive. Since $h$ is large, the second term dominates. Hence the derivative is positive for any $s$ satisfying $s>c(b+r)$. Thus, when $b<(1 / c-r)$, capitalists' best reply is to save at their maximal rate.

Note that throughout, current profits $P(0)$ are assumed to be positive. If profits, adjusted for cyclical fluctuations not included in our model, were not positive, capitalists would disinvest and compromise would break down.

The proof of the workers' best-reply theorem proceeds in the same way. From the definition of class compromise (equation 8 ), we can write

$$
\begin{gathered}
W(t)=W^{\prime}(0)+\sum_{i=0}^{i=t-1} \Delta W(i)= \\
=W(0)+r \sum_{i=0}^{i=t-1} P(i) .
\end{gathered}
$$

To get the expression for $W^{*}$, substitute (A1) into (A3), expand the geometric series, substitute the resulting expression for $W^{\prime}(t)$ into equation (11), expand the geometric series again, and collect and rearrange terms. The algebra is tedious but straightforward. The result is:

$$
\begin{aligned}
W^{*} & =\frac{(1+a)}{a}\left[W(0)+\frac{r P(0)}{(r-(s / c-a))}\right] \\
& -\frac{1}{a(1+a)^{h}}\left[W(0)+\frac{r P(0)}{(r-s / c)}\right] \\
& +\frac{(1+a) r P(0)}{(r-s / c)(r-(s / c-a))}\left[\frac{g-r}{1+a}\right]^{h+1},
\end{aligned}
$$

where $g=1+s / c$.

Let $h$ approach infinity. Note first that since $a$ $>0$, the second term of $w^{*}$ vanishes. Now consider the case in which $s / c<a$. It follow that $(g-r) /(1+a)<1$, which implies that the final term vanishes as well (since $g<(1+a)$ and $r>0$ ). Thus, $W^{*}$ is dominated by the first term for $h$ sufficiently large. The derivative of this term with respect to $r$ is

$$
\frac{\partial W^{*}}{\partial r}=\frac{(1+a) P(0)(a-s / c)}{a(r-(s / c-a))^{2}} .
$$

Since, by hypothesis $(a-s / c)>0$, this derivative is positive for any value of $r$. The best-reply strategy of workers is to be maximally militant.

Now let the rate of saving chosen by capitalists by such that $s / c>a$ (which is possible only if $1 / c>a$ ). Workers face the following choice. If they choose an $r$ such that $r$ $>(s / c-a)$, then again $(g-r) /(1+a)<1$, the final term vanishes, and $W^{*}$ is bounded above for all $h$. If workers, however, choose a less militant $r$ such that $r<(s / c-a)$, the last term of $W^{*}$ is positive and increasing without bound as $h$ grows. Hence, for all $h$ sufficiently large, the less militant choice is superior. Now as $h$ approaches infinity, it is the last term of (A4) which dominates. Taking its derivative with respect to $r$ :

$$
\frac{\partial W^{*}}{\partial r}=\left\{\frac{\partial A}{\partial r}\left[\frac{g-r}{1+a}\right]-\frac{A(h+1)}{(1+a)}\right\}\left[\frac{g-r}{1+a}\right]^{h}
$$

where

$$
A=\frac{(1+a) r P(0)}{(r-s / c)[r-(s / c-a)]} .
$$

Since $r<(s / c-a), A>0$ and the second term inside the brackets is negative. As $h$ approaches infinity, this term dominates. Therefore, the derivative is negative for all values of $r$ satisfying $r<(s / c-a)$. When $a<s / c$, the workers' best reply is their minimal level of militancy. As the horizon becomes infinite, $r^{*}$ approaches zero.

\section{References}

Bowles, Samuel, and Gintis, Herbert, 1980. The crisis of liberal democratic capitalism: the case of the United States. Presented at the annual meeting of the American Political Science Association, Washington, D.C.

Chiaramonte, Gerardo. 1975. Report to the Central Committee of the P.C.I. October 29-30. Italian Communist.

Clough, Shepard B. 1968. European economic history. New York: McGraw-Hill.

Edel, Matthew. 1979. A note on collective action, Marxism, and the prisoner's dilemma. Journal of Economic Issues 13:751-61.

Ferejohn, John, and Page, Talbot. 1978. On the foun- 
dations of intertemporal choice. American Journal of Agricultural Economics 78:269-75.

Glyn, Andrew, and Sutcliffe, Bob. 1972. Capitalism in crisis. New York: Pantheon Books.

Goldberg, Samuel. 1958. Introduction to difference equations. New York: John Wiley and Sons.

Gramsci, Antonio. 1971. Prison notebooks. New York: International Publishers.

Griffuelhes, Victor. 1910. L'Inferiorité des Capitalistes Francais. Mouvement Socialiste 226:329-32.

Harsanyi, John C. 1977. Rational behavior and bargaining equilibrium in games and social situations. Cambridge: Cambridge University Press.

Heller, Agnes. 1974. The theory of need in Marx. London: Allison and Busby.

Helmstädter, Ernst. 1973. The long-run movement of the capital-output ratio and of labor's share." In James Mirrlees and N. H. Stern (eds.). Models of economic growth. London: Macmillan.

Hoel, Michael. 1975. Aspects of distribution and growth in a capitalist economy. Memorandum of the Institute of Economics. Oslo, Norway: University of Oslo.

(1978). Distribution and growth as a differential game between workers and capitalists. International Economic Review 19:335-50.

Jacobsen, John K. 1980. Chasing progress. Ph.D. dissertation. University of Chicago.

Keynes, John M. 1936. The general theory of employment, interest, and money. New York: Harcourt, Brace, Jovanovich.

Kolm, Serge-Christophe. 1977. La Transition So $\rightarrow$ cialiste: La Politique Economique de Gauche. Paris: Editions du Cerf.

Kuznets, Simon. 1966. Modern economic growth: rate, structure, and spread. New Haven: Yale University Press.

Lancaster, Kelvin. 1973. The dynamic inefficiency of capitalism. Journal of Political Economy 81:10921109.

Lange, Oskar. 1938. On the economic theory of socialism. In Benjamin Lippincott (ed.). On the economic theory of socialism. Minneapolis: University of Minnesota Press.

Maddison, Angus. 1964. Economic growth in the west. New York: W. W. Norton.

Marx, Karl. 1934. The eighteenth brumaire of Louis Bonaparte. Moscow: Progress Publishers. lishers.
1972. Writings on the Paris commune. Edited by Hal Draper. New York: Monthly Review.

McDonald, Ian M., and Solow, Robert M. 1981. Wage bargaining and employment. American Economic Review 71:896-908.

Miliband, Ralph. 1969. The state in capitalist society. New York: Basic Books.

Nash, John. 1954. Equilibrium states in n-person games. Proceedings of the National Academy of Sciences 36:48-9.

Odling-Smee, J. C. 1973. Personal saving revisitedmore statistics, fewer facts. Oxford Bulletin of Economics and Statistics 35:21-9.

O'Donnell, Guillermo A. 1973. Modernization and bureaucratic-authoritarianism: studies in South American politics. Berkeley: Institute of International Studies, University of California.

Offe, Claus, and Wiesenthal, Helmut. 1980. Two logics of collective action: theoretical notes on social class and organizational form. Political Power and Social Theory 1:67-115.

Pasinetti, Luigi L. 1962. Rate of profit and income distribution in relation to the rate of economic growth. Review of Economic Studies 29:267-79.

Pirker, Theo, ed. 1965. Komintern und Faschismus. Stuttgart: Deutsche Verlags-Anstalt.

Poulantzas, Nicos. 1973. Political power and social classes. London: New Left Books.

Przeworski, Adam. 1980. Material bases of consent: politics and economics in a hegemonic system. Political Power and Social Theory 1:23-68.

Roemer, John E. 1979. Mass action is not individually rational: reply. Journal of Economic Issues 13: 763-7.

in press. The labor-theory-of-value approach to Marxian exploitation is in general wrong. Politics and Society.

Sombart, Werner. 1976. Why there is no socialism in the United States. White Plains, N.Y.: International Arts and Sciences.

Stackelberg, H. von. 1952. The theory of the market economy. Translation and Introduction by A. T. Peacock. London: William Hodge.

Taylor, Michael. 1976. Anarchy and cooperation. London: John Wiley and Sons.

Wallerstein, Michael. 1979. An estimate of savings out of wages in the United States, 1949-1970. Unpublished. University of Chicago. 